\title{
Flexible Design in Algerian Collective Housing. Case of the New City Ali Mendjeli, Constantine
}

\author{
Imane Benkechkache ${ }^{1}$ | Bouba Benrachi ${ }^{2}$ \\ Received: 2020-12-17 | Final version: 2021-05-19
}

\begin{abstract}
This paper examines flexible design in housing and its relation to the appropriation of domestic space by users. Several significant definitions have been exposed about this concept and make it possible to state that indeed, flexible design concedes to achieve all possible spatial transformations in housing. These are carried out to follow lifestyles evolution of inhabitants by allowing them a better adaptation and an easy use. The objective of this study is to estimate the degree of flexibility in the design of collective housing in Algeria through the analysis of construction criteria - adaptation and transformation-, defined by several researchers, which allow to reach a high flexible design. A study is carried out on two types of collective housing, located in the new city Ali Mendjeli, extension of Constantine, containing large housing programs and having undergone many transformations. A diagnosis is realized on these dwellings to evaluate the flexible design degree through the analysis of the transformations carried out by inhabitants. A comparative analysis is established between the two types of housing to identify which one has a better degree of flexible design. The obtained results show that transformations carried out on these dwellings, allow to reach an acceptable degree of flexibility about studied criteria for the two types of dwellings. However, the housing with better design characteristics, namely, surface and type of flexible structure, presents a better degree of flexible design and can be recommended as a model.
\end{abstract}

Keywords: Adaptability; transformation; lifestyle; flexibility

Citation

Benkechkache, I. \& Benrachi, B. (2021). Flexible Design in Algerian Collective Housing. Case of the New City Ali Mendjeli, Constantine. ACE: Architecture, City and Environment, 16(47), 10030. DOI: http://dx.doi.org/10.5821/ace.16.47.10030

\section{Diseño flexible en viviendas colectivas argelinas. El caso de la nueva ciudad Ali Mendjeli, Constantine}

Abstract

\begin{abstract}
Este artículo examina el diseño flexible en la vivienda y su relación con la apropiación del espacio doméstico por parte de los usuarios. Se han expuesto varias definiciones significativas sobre este concepto y permiten afirmar que efectivamente, el diseño flexible concede lograr todas las transformaciones espaciales posibles en la vivienda. Se realizan con el fin de seguir la evolución de los estilos de vida de los habitantes permitiéndoles una mejor adaptación y un fácil uso. El objetivo de este estudio es estimar el grado de flexibilidad en el diseño de viviendas colectivas en Argelia a través del análisis de criterios constructivos -adaptación y transformación-, definidos por varios investigadores, que permiten alcanzar un diseño altamente flexible. Se realiza un estudio sobre dos tipos de viviendas colectivas, ubicadas en la nueva ciudad Ali Mendjeli, extensión de Constantine, que contienen grandes programas habitacionales y que han sufrido muchas transformaciones. Sobre estas viviendas se realiza un diagnóstico con el fin de evaluar el grado de diseño flexible a través del análisis de las transformaciones realizadas por los habitantes. Se establece un análisis comparativo entre los dos tipos de vivienda para identificar cuál tiene un mejor grado de diseño flexible. Los resultados obtenidos muestran que las transformaciones realizadas en estas viviendas permiten alcanzar un grado de flexibilidad aceptable respecto a los criterios estudiados para los dos tipos de viviendas. Sin embargo, la vivienda con mejores características de diseño, a saber; superficie y tipo de estructura flexible, presenta un mejor grado de diseño flexible y puede recomendarse como modelo.
\end{abstract}

Palabras clave: Adaptabilidad; transformación; estilo de vida; flexibilidad

${ }^{1}$ Assistant lecture; Saleh Boubnider Constantine3 University, Faculty of Architecture and Urban Planning, LAUTES Laboratory, ${ }^{2}$ Professor; Saleh Boubnider Constantine3 University, Faculty of Architecture and Urban Planning, LAUTES Laboratory. Contact e-mail: imane.benkechkache@univ-constantine3.dz

ACE, 16 (47) CC BY-ND 3.0 ES | UPC Barcelona, España | Flexible Design in Algerian Collective Housing. Case of the New City Ali Mendjeli, Constantine. DOI: http://dx.doi.org/10.5821/ace.16.47.10030 


\section{Introduction}

Flexible design refers to constructions that are designed to respond easily to different changes during their lives and offer considerable advantages. They are usable for longer periods of time, can accommodate experience and technical intervention, are better suited to their purpose and are more viable from an economic, ecological, cultural, and social point of view (Kronenburg; 2007). Indeed, several researchers agree that a flexible designed space, in particular housing as well as its component parts, accepts all possible transformations carried out by users in order to respond to appropriate use, changing needs and present and future lifestyles (Schnieder and Till; 2007; Sánchez, 2013; Friedman, 2014 in Baradaran, 2019; Ritter and Nuno, 2018). These changing needs can be of social character (changes in family size or number of households, aging of inhabitants, changes in practices), technological character (modernization of services and innovations in domestic equipment), economic character (the rise of the rental market) and environmental character (climate change and development in energy) (Schnieder and Till, 2007).

For this purpose, flexible housing design can be considered as an imperative solution that allows to carry out transformations of the housing space and to follow the changes that appear with inhabitants' lifestyle development. According to Frommes, housing is the place where people should feel at home; they take possession of it and experience their personality; they can identify optimally with it (Frommes, 1980 in Heraoubia, 2011). Also, according to Lamure, a family's lifestyle could be defined as the distribution in time and space of the family's and its member's activities (Lamure, 1976).

Therefore, this research takes into consideration the study of Algerian collective housing design and its relationship with living ways and the adaptation of domestic space by the users. A problematic which questions the production mode of housing, which is interested, until today, much more by quantity to the detriment of quality forgetting lifestyle evolution and the changes of users' needs. Several studies report that Algerian collective housings that have been built do not conform to present needs, and cannot meet inhabitants' future needs (Benrachi, 2004; Leghmouche, 2009; Foura, 2007).

This problem is the result of a housing crisis that has been dragging on since 1962 in the urgency of mass construction. However, in recent years, research has focused on developing solutions through flexible, adaptable, and sustainable design. On the one hand, to improve the quality of these dwellings and meet inhabitants present needs, and on the other hand, to avoid the degradation of constructions during or after work transformations of these dwellings. Certainly, in 1997 the Algerian state decided to promote the development of the great economic balances, with introduction of new formulas for the housing acquisition by involving citizen in the financing. These formulas are defined according to the incomes of beneficiaries and are in number of four namely, the Public Rental Housing (PRH), the Participative Social Housing (PSH), Rental-Sale Housing (RSH) and the Public or Private Promotional Housing (PPH):

- Public rental housing (PRH): intended for low-income households not exceeding 180.27 USD or for the re-housing of slum dwellers. These dwellings are of F2 and F3 types (2 and 3 bedrooms) with a surface area varying between 50 and $60 \mathrm{~m}^{2}$ (Jora, 1998; Jora, 2000).

- Participatory social housing (PSH): intended for middle-income households with an average income of less than 300.45 USD. The dwellings are of F3 type (3 bedrooms) with a surface area of $70 \mathrm{~m}^{2}$ (Jora, 1994; Jora, 2001).

- $\quad$ Rental and sale Housing (RSH): intended for households with income not exceeding five (5) times the SNMG (guaranteed minimum national wage) or $300.45 \mathrm{USD} / \mathrm{month}$. The dwellings are of $\mathrm{F} 3$ and $\mathrm{F} 4$ types ( 3 and 4 bedrooms) with respective surface areas of $70 \mathrm{~m}^{2}$ and $85 \mathrm{~m}^{2}$ (Jora, 2001).

ACE, 16 (47) CC BY-ND 3.0 ES | UPC Barcelona, España | Flexible Design in Algerian Collective Housing. Case of 
The first three housing formulas mentioned above (PRH, PSH and RSH) are intended for a social category, which is based on income and state support.

- Public or private promotional housing (PPH): intended for households with incomes between 6 and 12 times the SNMG. A housing of high standing and more performing architectural quality intended for higher social classes. This type of housing is characterized by the procedure "sale on plan" which gives the purchaser the possibility to personalize it. The public $\mathrm{PPH}$ dwellings are of F3, F4 and F5 types and duplexes with respective surface areas of 80 $\mathrm{m}^{2}, 100 \mathrm{~m}^{2}$ and $120 \mathrm{~m}^{2}$. Private PPH dwellings are marked by surface area exceeding $200 \mathrm{~m}^{2}$ (Jora, 1986; Jora, 1993; Jora, 1994; Jora, 2001).

Regardless of all these efforts, the new objectives of housing policy in Algeria are not different from the previous ones, especially about the spatial design of collective housing for the first three formulas. A policy that focuses much more on the quantitative and economic aspects, without taking into consideration the changes in the structures of families, their lifestyles, and the way of domestic space appropriation. Especially since the Algerian family is characterized by a size varying from 4 to 10 persons per household and a national occupancy rate per dwelling of 4.14 persons per dwelling (Ministère de l'habitat, de l'urbanisme et de la ville, 2015; ONS, 2020). However, contemporary social collective housing makes no reference to traditional architectural forms; it has been realized as it was conceived in Western Europe without adaptation to Algerian context particularities. There is a huge difference between the production mode and lifestyle of domestic space, which justifies the different internal and external transformations carried out in housing according to family's needs and social practices (Foura, 2007). Similarly, most of these dwellings are altered by transformations made by users before or after occupancy to meet their needs for an appropriate lifestyle. Also, these transformations carried out without expertise may lead these dwellings to deteriorations and degradations in their structures, exposing them to the risk of collapse in the event of natural disasters (Benrachi and Lezzar, 2013).

These different consequences have been revealed by several researchers in the construction of social collective housing who examined the difference in internal spatial design between demand and supply as well as family size, shape, and surface area of the housing (Lezzar, 2000; Benrachi, 2004; Tebbib, 2008). Conversely, collective promotional housing, which is totally financed by the user, is different from other types of social housing, particularly in terms of quality, construction materials, surface area and size (Bourahli, 2009; Rifi, 2008). From what has been presented previously and as an imperative response to the housing problem in Algeria, flexible design becomes an important concern in the design of Algerian collective housing. This study, therefore, aims to examine the contribution of the flexibility sought by several authors in the design of housing, which provides answers to the questions of this research namely:

- What are the consequences of design that is unsuited to people's lifestyles?

- What is the degree of spatial and structural satisfaction of inhabitants with their housing?

- How to improve the degree of flexibility of Algerian collective housing?

\section{Flexibility in space design: Literature Review}

This research focuses on flexible design and how it enables the improvement of the design quality of collective housing that better meets the changing needs and lifestyles of users in a sustainable manner. It is therefore essential to concentrate on the different definitions and explanations given by different researchers on lifestyle, flexibility, sustainability, and their impact in housing design. Similarly, it is necessary to identify the construction criteria of flexible design to be able to assess the degree of flexibility in housing.

ACE, 16 (47) CC BY-ND 3.0 ES | UPC Barcelona, España | Flexible Design in Algerian Collective Housing. Case of the New City Ali Mendjeli, Constantine. DOI: http://dx.doi.org/10.5821/ace.16.47.10030 


\subsection{Lifestyle and flexibility}

The lifestyle concept represents the society habits' where everyone has different ways of life. And the family's lifestyle could be defined as the distribution of activities in time and space of the family and its members. Thus, changes in lifestyle appears by the changes of the large family to nuclear family, the disappearance of economic functions in dwelling, the reduction of educational functions at home, the simplification of domestic functions by the generalization of female activities, the redistribution of roles, the internationalization of actions, etc.

So, according to research work conclusions of Breton's, it emerges that in recent decades lifestyles have changed a lot and consequently it has become imperative to review the interior design of housing to produce spaces with new forms and more adapted to the family's daily life. To meet the everchanging needs of future generations, the architect must be in clear harmony with these changes (Le Breton, 2015). In the same logic, Saez emphasizes that with flexible architecture there is the possibility of creating housing that is adaptable to domestic group life. This design can meet the needs of one people during the week and six people during the weekend. Flexibility then becomes an effective solution to different lifestyles by adapting housing to needs during the lifetime (Saez, 2012).

\subsection{Flexible design in the housing context}

Several authors in their publications agree that the purpose of flexibility in spatial design is to provide a private property with the capacity to accommodate different physical arrangements to meet different expectations of occupants. The same applies to the layout of permanent and fixed parts of the building, namely structural system, and technical services (Rabeneck et al, 1973 in Albostan, 2009; Groak, 1992 in Golshid, 2012). Also, this spatial design must allow over time internal transformations of space, particularly housing, with changes in the position of rooms, their size, number, and destination. In the same way the maximum modifications that can only be obtained by the mobility of technical services (Chatelet et al, 1995; Schneider and Till, 2005(b)).

In their research Schneider and Till integrate the physical structure of the building into this concept and highlight that flexibility is only satisfied by change in this structure. It must consider the problems of form and technical construction. As well, Živković and Jovanović say that: "The evolution of social behaviour leads to new conceptual solutions of modern living, new principles of housing unit design and its immediate environment. Residential environment should be designed to respond to the modern living demands, with the idea of flexibility as a key feature of design approach" (Živković and Jovanović, 2012).

Finally, for Kronenburg, flexible design is determined by four main construction criteria (adaptation, transformation, displacement, and interaction) and can only be achieved when inhabitants take ownership of their living space. These criteria are defined as follows:

- Adaptation: A design that has multiple uses with versatility; it is an architecture called: "Open building". Adaptable architecture concerns buildings that are designed to adapt to their environment and to the needs of the inhabitants (Kronenburg, 2007; Lelieveld et al, 2007; Schnädelbach, 2010).

- Transformation: is a construction that allows both internal and external changes. For instance, it presents all physical alterations to the structure, the exterior envelope, and the interior space of the building (Kronenburg, 2007).

- Displacement: is a construction that can change site. This relates to constructions that are transported from one site to another so that they better fulfil their functions. It is an architecture that rolls floats or flies (Kronenburg, 2007).

ACE, 16 (47) CC BY-ND 3.0 ES | UPC Barcelona, España | Flexible Design in Algerian Collective Housing. Case of 
- Interaction: is a construction that automatically meets the needs of users, called: "smart buildings". This includes buildings that respond to user requests automatically or intuitively. This architecture uses detectors that trigger changes in appearance, environment, or services, thanks to kinetic systems and intelligent materials (Kronenburg, 2007).

However, in our research work only the first two construction criteria for flexible design, namely "Adaptation" and "Transformation" will be examined. They are involved in the improvement of spatial and structural satisfaction of inhabitants, which can be maintained throughout the life process of the housing space denoted by sustainability.

\subsection{Sustainability in flexible housing design}

According to Schneider and Till, flexibility is more economical in the long run because the obsolescence of the housing stock is limited, and the housing will last longer and be cheaper in the long run, reducing the need for major renovations or relocation. (Schneider and Till, 2005(a)). Broome sees flexibility as an inherent part of a sustainable system, as building construction must have a longlife span and respond to changing needs and aspirations (Broom, 2005 in Schneider and Till, 2007). Similarly, Lans and Hofland noted that flexible design aims for the durability of construction up to 200 years (Lans and Hofland, 2005).

\subsection{Flexible design criteria}

From what it has been presented by different researchers on flexible design, many studies in particular Živković and Jovanović ones', as a new approach in housing architectural design, identified pertinent indicators on space design and organization that largely affect the flexibility degree inside the dwelling and give the possibility to establish heavy or light transformations according to the changing needs of the users (Lelieveld et al, 2007; Schneider and Till, 2007 in Albostan, 2009; Schnädelbach, 2010; Živković and Jovanović, 2012; Estaji, 2017; Ritter and Nuno, 2018). Generally, the degree of flexibility in housing through the analysis of adaptation and transformation criteria is expressed by spatial and structural satisfaction of users.

\section{- Adaptation criteria}

Designing adaptable architecture means recognizing that the future is undefined and changes in living space are inevitable. Consequently, adaptable constructions are intended to respond easily to different modes of use and user requirements and construction elements involved in adaptation according to (Schnadel Bach, 2010) and (Lelieveld et al, 2007) are:

- Internal and external surfaces of the building (changes in the characteristics of the walls (finishes): facades, floors, ceilings (roofs) and partitions)

- Components and modules (the displacements of the partition walls)

- Spaces (enlargement, reduction, closing, opening and change of position and function)

- Elements of the building system such as: the building structure and building components (walls, floors, and ceilings, etc.)

- The technical installations (water, electricity, gas, drainage, heating, ventilation), wiring and piping, and finally the environmental aspects (sensory level, intensity and colour of lighting) (Kronenburg, 2007; Harper, 2003; Streitz et al 1999; Bullivant, 2005; Schnadel bach et al, 2007 in Schnädelbach, 2010; Lelieveld et al, 2007).

The indicators of adaptable construction are defined as follows:

ACE, 16 (47) CC BY-ND 3.0 ES | UPC Barcelona, España | Flexible Design in Algerian Collective Housing. Case of 


\section{The orientation of the dwelling}

The position and the number of facades in dwelling have a direct impact on the spatial organization of housing and especially on the degree of internal flexibility of housing. The optimal solution is to have several possible facades in dwelling, resulting in more spacious and flexible areas in free interpretation with lots of lighting and ventilation. To this criterion of dwelling orientation, other criteria must be also considered, such as the shape and size of the dwelling. We can distinguish three types of orientation: unilateral, bilateral or three orientations.

- Unilateral orientation: flexibility in this spatial organization is limited by the fact that the rooms can be arranged only along a single facade and a minimum variation of the house architectural plan. Also, the main drawback of this type of orientation is the limitation in the interior natural lighting and ventilation.

- Bilateral orientation: the degree of flexibility is high giving more freedom in the internal spatial organization of the dwelling which depends on the geometry of the plan. In this case, the spatial organization is better in the square shape architectural plan than in the elongated one, because it offers more freedom to divide the space at Day/ Night. In addition, the living areas are spread over the two opposite facades, which make it possible to divide the space in different ways without reducing the quality and value of use. However, Živković and Jovanović concluded in their assessment that bilateral orientations differ in practice where there is a bilateral orientation with two opposite or adjacent facades (Živković and Jovanović, 2012). Although, the opposite bilateral orientation is better in terms of flexibility and organization of the internal space, with the possibility of offering more lighting and natural ventilation in comparison with the adjacent bilateral orientation, more particularly in case of the elongated shape of the housing.

- Triple orientation: offers more opportunities in flexibility and space organization. The living area is arranged on three sides, resulting in more spacious and flexible areas with plenty of light and ventilation and free interpretation.

The plan geometry

It directly affects the degree of flexibility in the organization and use of domestic space. The possibility of change in rooms number and size are greater with a more compact, simple and regular shape. This form provides a free plan with more conceptual flexibility in terms of organization and versatility in the use of the internal space of the dwelling. This plan can also take unpredictable functions that appear over time, unlike the irregular one which is less flexible in the organization and use of space. (Živković and Jovanović, 2012).

Size of dwelling in relation to the family structure

The family is an evolving elastic structure which adapts to different internal and external influences; it undergoes changes at every stage of a generation's life. The evolution in a family structure requires a direct link with the change in the size of the dwelling which represents a static variable, which cannot meet all the changing needs of the family over time. The latter must adapt to the physical conditions of the space. One of the possibilities for improving quality and use value is the flexibility of the dwelling in terms of internal changes in its spatial configuration. Živković and Jovanović determined, on the one hand, that the size of the dwelling has much more influence on the use value compared to the family structure (Živković and Jovanović, 2012). On the other hand, the degree of variety of architectural plans depends on the size of the dwelling.

According to the technical standards of design defined, a minimum size of family structure of a young couple with/without children can provide a greater flexibility in the space organization which is

ACE, 16 (47) CC BY-ND 3.0 ES | UPC Barcelona, España | Flexible Design in Algerian Collective Housing. Case of 
estimated to be with a total area of about $\left(70 \mathrm{~m}^{2}\right)$. This area will give a sufficient degree of flexibility in terms of size in the event of a possible extension of the family.

Number and disposition of the entrance

Has a lot of influence on its internal organization as well as on the level of flexibility; it can take two central or peripheral dispositions. The central position is generally the best placement because it presents direct and shortest possible link to relevant parts of the dwellings.

A solution, which gives possibility of rotating Day and Night spaces, without compromising the quality and use value compared with peripheral access position, it particularly in large dwellings with an elongated shape which causes a big interruption between the different parts of the housing. (Živković and Jovanović, 2012).

\section{Technical services position}

It is one of the fundamental and unchangeable aspects in the housing unit. The structuring of the technical core is an important thing to be considered in the initial design phase to give more flexibility in operation. The technical core, including the installation block and walls, can have a variety of functions, such as: Kitchen, bathroom, WC, cupboards, vertical communications (staircase / elevator). The position of the technical services within the dwelling can be:

- Independent at the central part of the dwelling: It gives various solutions for spatial organization around it. It encourages circular connection in the housing which increases the use value of its space. There is also the possibility of positioning the Day/Night space in different ways around the service block. This position offers a higher degree of flexibility in the housing.

- Central, along one or more walls of the dwellings with the use of the free architectural plan in the intervention and the neutrality (undetermined) of the functions. It is possible in such a case to change the functions and to give the possibility of combining spatial organization with biological rhythm.

- Along the wall between two dwellings sharing a common area (stairs). This position reduces the opportunities for flexibility in spatial organization compared to usage (Živković and Jovanović, 2012).

\section{Construction structure}

Is the fixed and rigid part in the dwelling, and which reflects the degree of flexibility in the whole spatial unit. There are two types of structural systems generally used in practice, one massive with load-bearing walls and the second skeletal structural system with beam-columns. The designer is the only one who can determine the structural system type required for the design. However, the first type of massive structure limits flexibility. Also, the creation of rooms can only take place in one direction and its degree of flexibility depends on the direction of the load-bearing wall inside the housing.

The main obstacle in the organization of space is the deficiency of the optimal environment, such as: natural lighting and ventilation. In contrast to the first type, the skeletal structural system offers many more opportunities in spatial organization in terms of quality and use value. This type of system provides a high level of structural flexibility, since the plane is opened in two orthogonal directions (Živković and Jovanović, 2012).

ACE, 16 (47) CC BY-ND 3.0 ES | UPC Barcelona, España | Flexible Design in Algerian Collective Housing. Case of 


\section{- $\quad$ Transformation criteria}

In architecture, transformation is synonymous with the space appropriation and the result of an antagonism between space and human needs (Benbouaziz, 2011). It is all the distinguished changes on the built environment; they can be changes in use and form at a given period (Angadi, 2014). The transformation is considered as the changes in the internal and external elements in the dwellings, namely, walls and facades. They can be hard or soft (Saighi, 2005; Schneider and Till, 2007; Albostan, 2009).

\section{Soft transformation}

It consists of changes in carpentry, painting, security, electrical and gas installations, maintenance, and aesthetic work.

Hard transformation

It consists of the removal, displacement, and construction of internal and external partitions.

To this end, the expected objective of this study is to estimate the degree of flexibility in the design of collective housing in Algeria through the analysis of the construction criteria identified by many researchers for spatial and structural satisfaction of inhabitants.

For this purpose, the study will focus on two types of collective housing with several variants, the $\mathrm{PRH}$ housing for the social and the PPH housing for the private promotion, carried out in the new city Ali Mendjeli, an extension of the old city of Constantine. This new city, which aims to accommodate the surplus population of Constantine and its surroundings since 2000, is essentially composed of large programs of new collective housing, containing about 80,000 housing units (ONS, 2020). The latter, just after their occupation, undergo different types of transformations by the users. In this context, the $\mathrm{PRH}$ housing represent approximately the greatest number of social housing construction of $70 \%$ (DUAC, 2009) and the PPH housing is considered as the most performed and accepted housing by users.

Thus, some points are taken into consideration in this study:

- The degree of satisfaction and appreciation of the spatial and structural of the dwelling.

- The ways of appropriating the domestic space in the context of adaptation and/or transformation.

Hence, the objective consists of verifying whether all the indicators of adaptability and transformation are present in the design of the housing studied to achieve a degree of internal flexibility that is satisfactory both in use and in form.

\section{Case study: collective social and promotional housing in new city Ali Mendjeli of Constantine}

\subsection{Methods and Materials}

This research was developed thanks to a sociological survey carried out using a questionnaire distributed to the inhabitants of the dwelling's examples studied, namely, 100 households in the PRH dwellings and 16 households in the PPH dwellings sited in the new city Ali Mendjeli of Constantine. An assessment of the condition of the latter was carried out based on several visits and drawings of the architectural plan of the dwellings concerned and based on the initial architectural plan design.

ACE, 16 (47) CC BY-ND 3.0 ES | UPC Barcelona, España | Flexible Design in Algerian Collective Housing. Case of 


\section{ACE Architecture, City and Environment}

This study is based first on the evaluation of the housing design through the analysis of adaptation and transformation criteria that influence directly flexible design and spatial organization of chosen housing examples. Then, an estimation of the flexible degree is accomplished through the evaluation of spatial and structural satisfaction of users.

Finally, a comparative analysis between the two types of dwellings cited above; social public rental housing (PRH) and private promotional housing (PPH) is accomplished.

This research is based on the study of initial plans design and the plans identified during the survey to identify and diagnose different transformations and explain the causes and the modes of adaptation of the inhabitants.

\subsection{Presentation of the example cases}

This research carried out of the two selected collective housing examples', with (100/616) Units of Public Rental Housing (PRH), social type, with three variants and (16/132) units of the Private Promotional Housing (PPH), high standard type, located in the new city Ali Mendjeli of Constantine.

\section{Situation}

Both collective housing examples are in the new city of Ali Mendjeli of Constantine, precisely in the neighborhood units NU 8 for the PRH and NU5 for the PPH. (Figures 1, 2 and 3).

Figure 1. Location of the programs the PPH in NU5 and PRH in NU8 neighborhood units

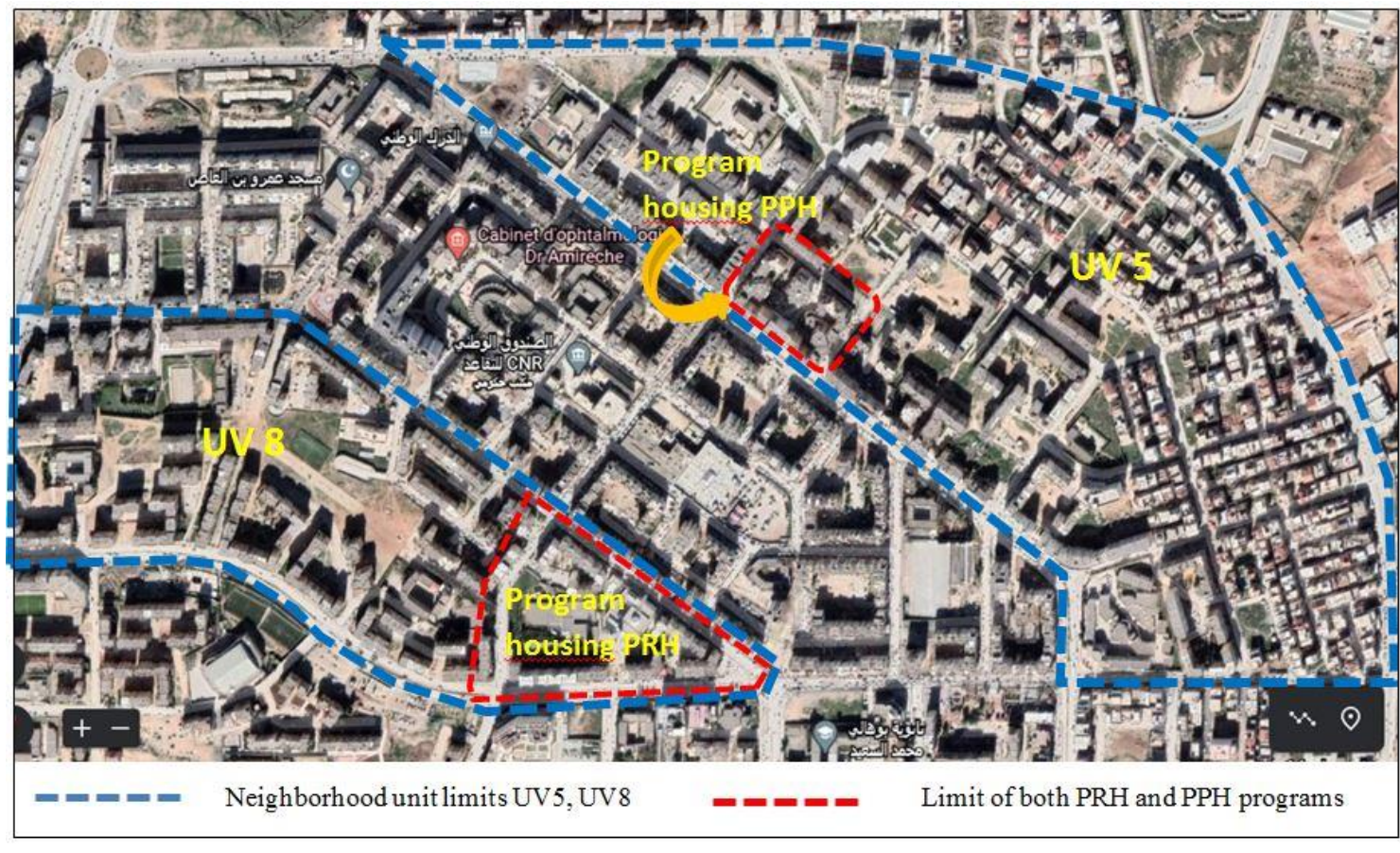

Source: Google Earth 2021.

ACE, 16 (47) CC BY-ND 3.0 ES | UPC Barcelona, España | Flexible Design in Algerian Collective Housing. Case of 


\section{ACE Architecture, City and Environment}

Figure 2. Location of PRH housing at NU 8

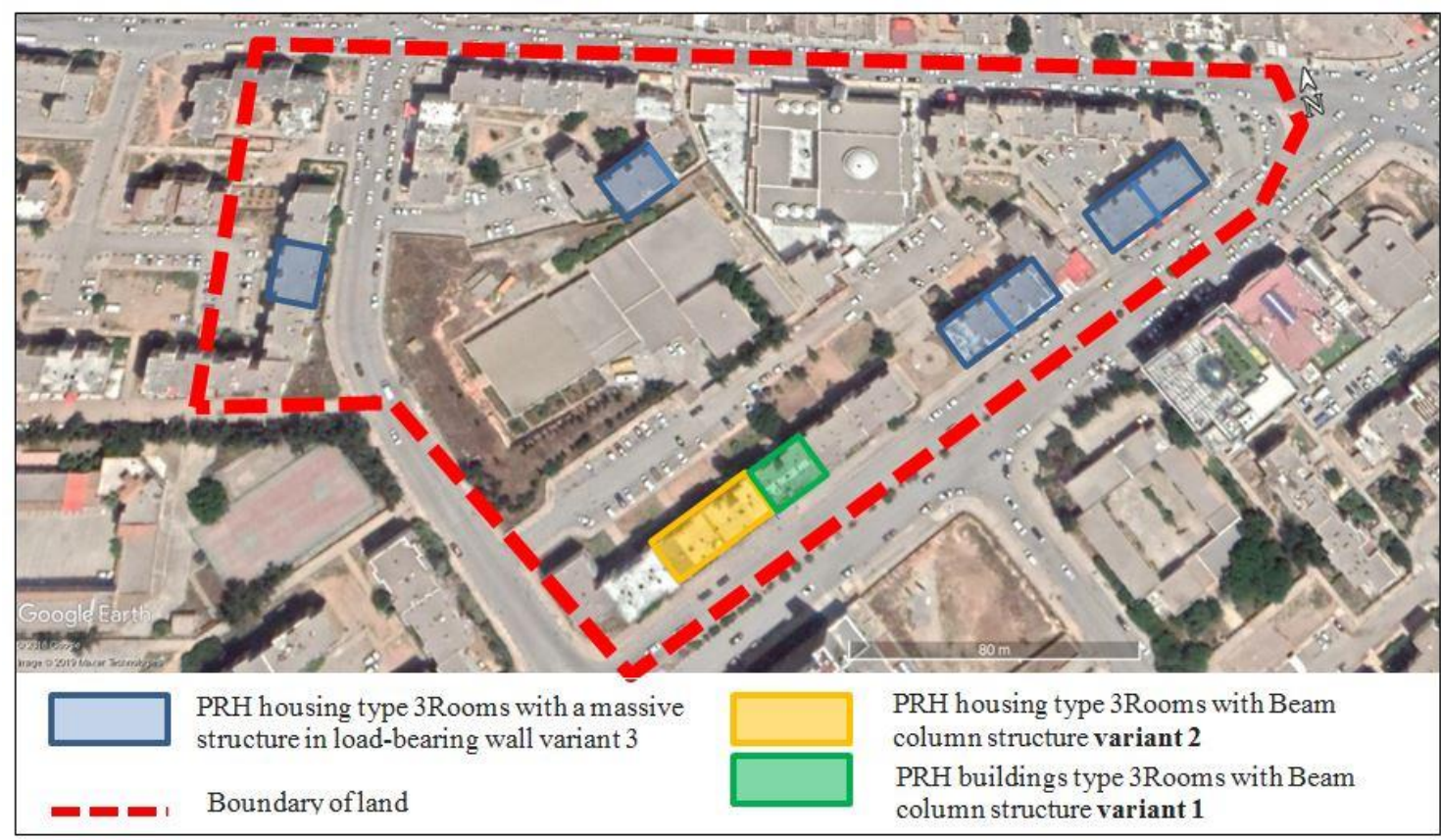

Source: Google Earth 2019.

Figure 3. Location of PPH housing at NU 5

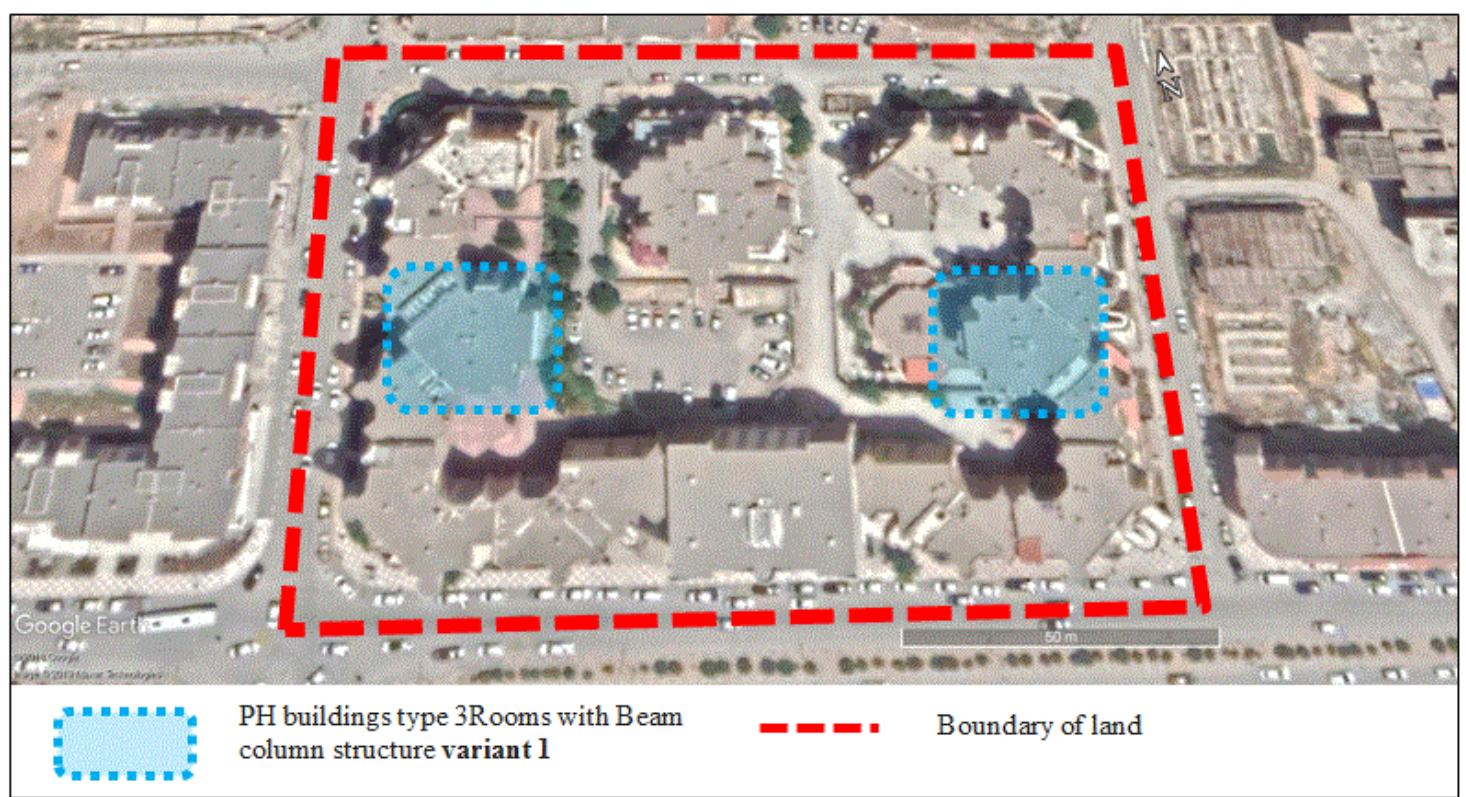

Source: Google Earth 2019.

\section{- $\quad$ Description of the Dwellings}

PRH social housing was built in 2000 with different structures, skeletal (beam-columns) structural system and load-bearing walls. Those of Ziani's Property Development were built at the beginning of the same year, with a beam-columns structural system.

ACE, 16 (47) CC BY-ND 3.0 ES | UPC Barcelona, España | Flexible Design in Algerian Collective Housing. Case of 
The (PRH) are 3BR (three bedrooms) dwellings of a regular compact shape with three variable overall areas ranging from $65.59 \mathrm{~m}^{2}$ to $76.17 \mathrm{~m}^{2}$. Similarly, the promotional (PPH) is marked by three types of cells 3BR, 4 BR, 5 BR, for which only the 3BR type studied has an area of $111.53 \mathrm{~m}^{2}$ and is characterized by a regular elongated shape (Table 1 and Figure 4).

Table 1. The areas of the housing studied PRH and $\mathrm{PH}$

\begin{tabular}{|l|c|c|c|c|}
\hline DESIGNATION & PRH Variant 1 & PRH Variant 2 & PRH Variant 3 & PH Variant 1 \\
\hline Living room & $12.53 \mathrm{~m}^{2}$ & $23.11 \mathrm{~m}^{2}$ & $18.43 \mathrm{~m}^{2}$ & $24.4 \mathrm{~m}^{2}$ \\
\hline Bedroom 1 & $15.12 \mathrm{~m}^{2}$ & $15.12 \mathrm{~m}^{2}$ & $11.40 \mathrm{~m}^{2}$ & $13.44 \mathrm{~m}^{2}$ \\
\hline Bedroom 2 & $13.87 \mathrm{~m}^{2}$ & $13.87 \mathrm{~m}^{2}$ & $9.30 \mathrm{~m}^{2}$ & $13.2 \mathrm{~m}^{2}$ \\
\hline Kitchen & $7.08 \mathrm{~m}^{2}$ & $7.08 \mathrm{~m}^{2}$ & $11.21 \mathrm{~m}^{2}$ & $12.76 \mathrm{~m}^{2}$ \\
\hline Bathroom & $2.50 \mathrm{~m}^{2}$ & $2.50 \mathrm{~m}^{2}$ & $3.42 \mathrm{~m}^{2}$ & $6.34 \mathrm{~m}^{2}$ \\
\hline Toilet & $2.50 \mathrm{~m}^{2}$ & $2.50 \mathrm{~m}^{2}$ & $3.42 \mathrm{~m}^{2}$ & $2.05 \mathrm{~m}^{2}$ \\
\hline Hall (Corridor) & $7.27 \mathrm{~m}^{2}$ & $7.27 \mathrm{~m}^{2}$ & $10.71 \mathrm{~m}^{2}$ & $21.28 \mathrm{~m}^{2}$ \\
\hline Total living area & $60.87 \mathrm{~m}^{2}$ & $71.45 \mathrm{~m}^{2}$ & $67.89 \mathrm{~m}^{2}$ & $93.47 \mathrm{~m}^{2}$ \\
\hline BALCONY & $2.36 \mathrm{~m}^{2}$ & $4.78 \mathrm{~m}^{2}$ & $3.42 \mathrm{~m}^{2}$ & $3.8 \mathrm{~m}^{2}$ \\
\hline DRYER & $2.36 \mathrm{~m}^{2}$ & $2.36 \mathrm{~m}^{2}$ & $3.42 \mathrm{~m}^{2}$ & $4.42 \mathrm{~m}^{2}$ \\
\hline Terrace & - & - & - & $5.83 \mathrm{~m}^{2}$ \\
\hline Cupboard & - & - & - & $111.53 \mathrm{~m}^{2}$ \\
\hline Total Usable area & $65.59 \mathrm{~m}^{2}$ & $76.17 \mathrm{~m}^{2}$ & $74.73 \mathrm{~m}^{2}$ & \\
\hline
\end{tabular}

Source: Architectural and urban planning office BET Ali Guechi and architectural and urban planning office the Ziani.

- $\quad$ The socio-professional characteristics of the inhabitants

Most of the inhabitants of these PRH and PPH dwellings are owners with a rate of about (90\%) for the first type and a rate of (81\%) for the second. The rest of the residents is tenants.

Regarding the socio-professional situation, most of the inhabitants of the PRH are employees and retirees with a rate of (37\%) for the first and (28\%) for the second. The rest are (17\%) as workers, a (12\%) function liberal, (5\%) senior managers and (1\%) unemployed. The inhabitants of the PPH are distributed with a high rate of (37\%) for senior managers, (25\%) for the liberal function and employees and finally (13\%) of retirees. (Figure 5)

- $\quad$ Analysis and results

According to the criteria adopted for the study of flexibility, which are adaptation and transformation, the analysis took into consideration the study of the housing architectural plan of their current inventory as well as the socio-professional survey of the inhabitants.

However, lifestyle analysis and the use of different spaces of these dwellings by inhabitants was carried out to understand how these transformations allow them to be satisfied, to adapt and meet their needs.

- $\quad$ Adaptation Study (Figure 4)

According to the analysis of adaptation indicators, the results of the study are as follows:

- Housing Orientation: Giving the housing architectural plans, the study shows that the two example cases have a bilateral orientation with opposite facades for the $\mathrm{PRH}$ and adjacent facades for the $\mathrm{PPH}$.

- Access of housing: The two types of dwellings have a single access with a central position for the PRH and the PPH dwellings.

ACE, 16 (47) CC BY-ND 3.0 ES | UPC Barcelona, España | Flexible Design in Algerian Collective Housing. Case of 11 the New City Ali Mendjeli, Constantine. DOI: http://dx.doi.org/10.5821/ace.16.47.10030 


\section{ACE Architecture, City and Environment}

Figure 4. (a) Architectural plan of PRH housing variant 1, (b) Architectural plan of PRH housing variant 2, (c) Architectural plan of PRH housing variant 3, (d) Architectural plan of PPH housing variant 1

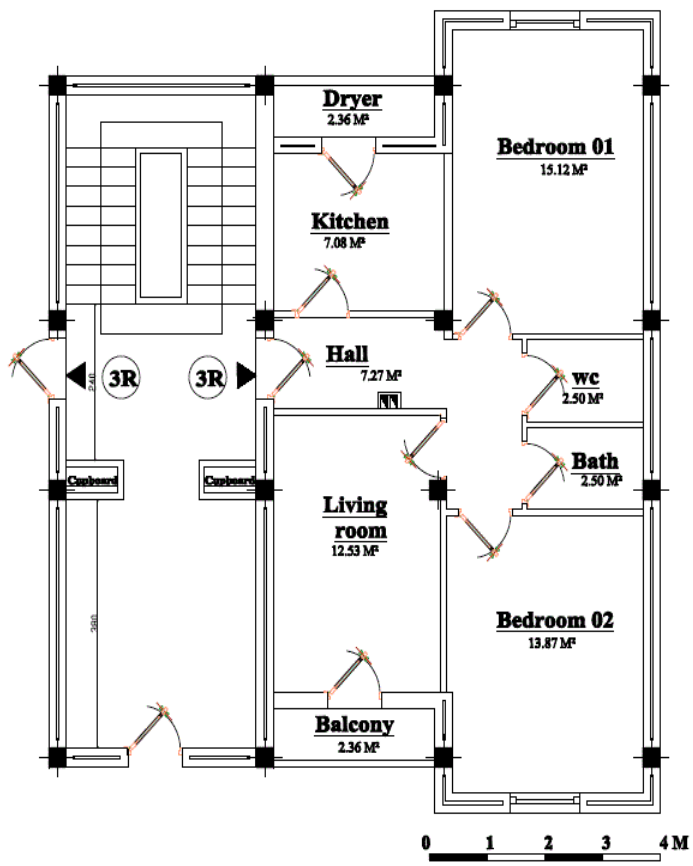

(a)

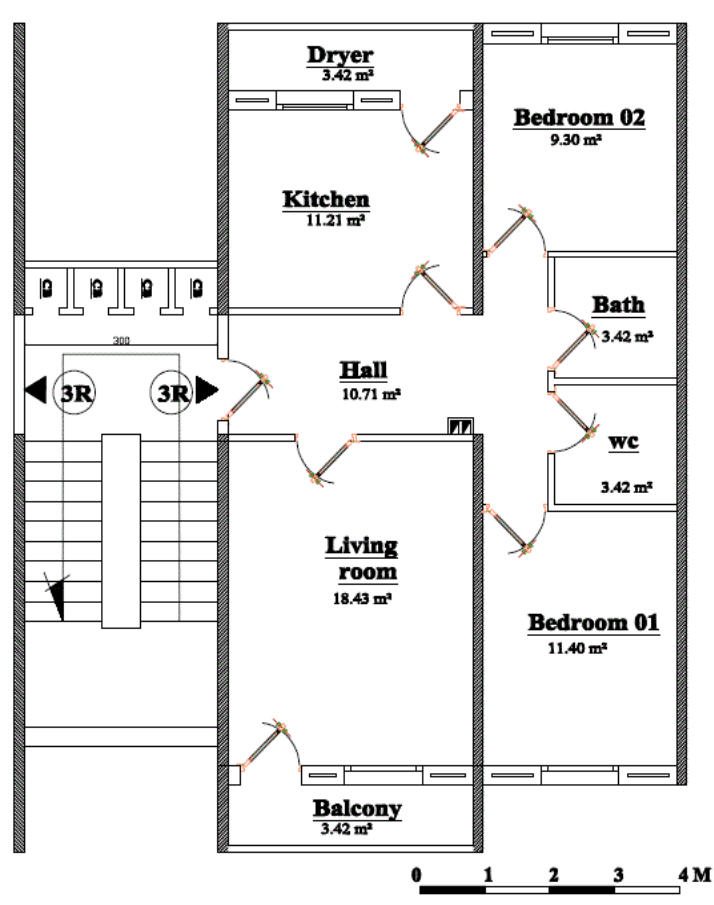

(c)

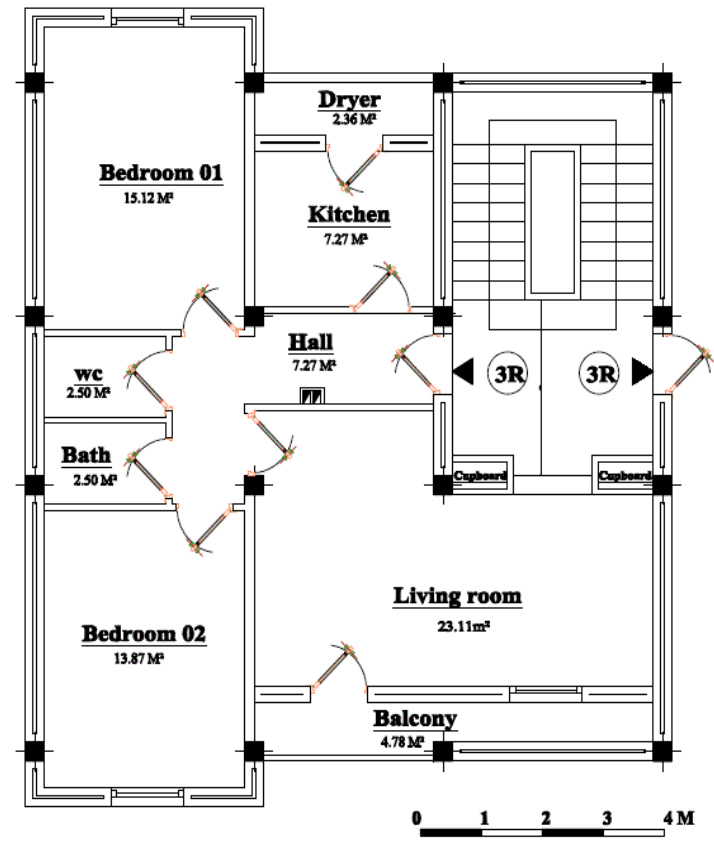

(b)

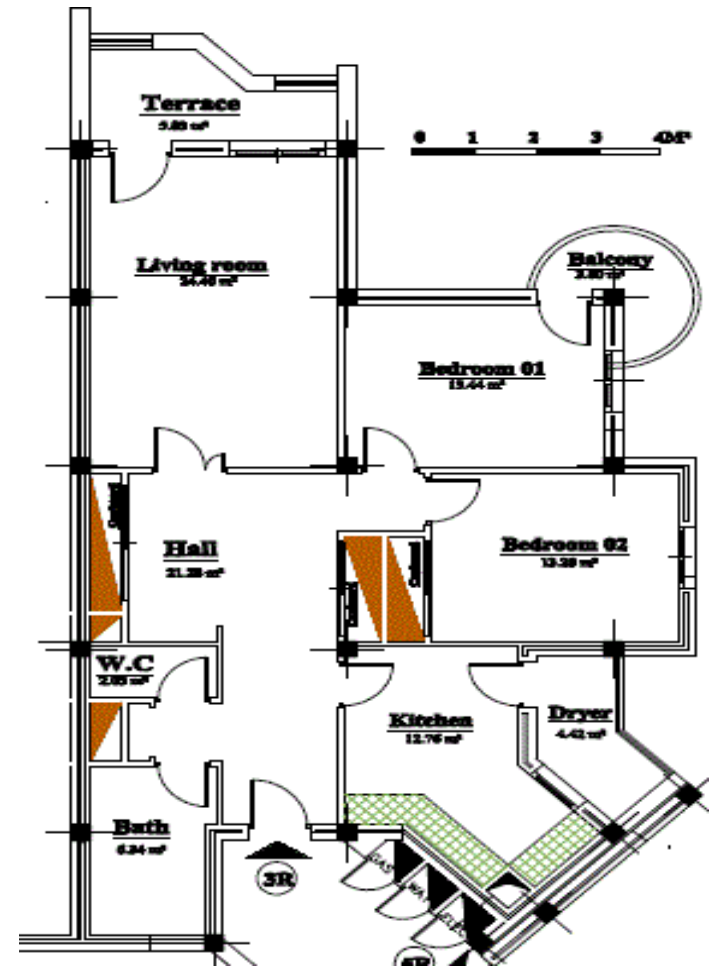

(d)

Sources: (a), (b), (c) Plan: BET (Office planning) Ali Guechi+ Authors survey, 2020); (d) Plan, BET Ziani.

ACE, 16 (47) CC BY-ND 3.0 ES | UPC Barcelona, España | Flexible Design in Algerian Collective Housing. Case of 
- Plan geometry: It presents a regular, simple, and compact shape for PRH and a regular and elongated shape for $\mathrm{PPH}$.

- Size of dwelling in relation to the family structure: The number of inhabitants per housing (TOL) in the PRH varies from 4 to 9 inhabitants per dwelling in 3bedrooms type $\left(65-76 \mathrm{~m}^{2}\right)$ with an average of 5.9, while that of the PPH varies from 3 to 5 inhabitants per dwelling in 3bedrooms type $\left(111 \mathrm{~m}^{2}\right)$ with an average of 4.5 .

Similarly, the occupancy rate per room (TOP) is 2 for the $\mathrm{PRH}$ and 1.5 for the PPH. It should be noted that the TOL in Constantine is 5.7 inhabitants per dwelling and the TOP is 2.2 inhabitants per room (ONS, 2020).

- Technical Services Position: It is consisting of kitchen, bathroom, and toilet, for the PRH are installed separately inside the dwelling. The kitchen is arranged along one of the two opposite facades of the dwelling and the bathroom and toilets are placed on the side of the blind wall of the apartment building in the central part of the architectural plan of the dwelling. While that of the $\mathrm{PPH}$, the kitchen is arranged along one of the two adjacent facades shared with another dwelling whereas the bathroom and toilets are arranged along the party a wall with another dwelling.

For both types of dwellings, the staircase is centered.

- Construction Structure: The PRH type is characterized by a variety of structures. Some are made of load-bearing walls, while others with beam-columns structural system such as those of the $\mathrm{PPH}$.

Figure 5. Professional status of the head of household of the $100 \mathrm{PRH}$ housing at NU8 and 16 PPH housing at NU5
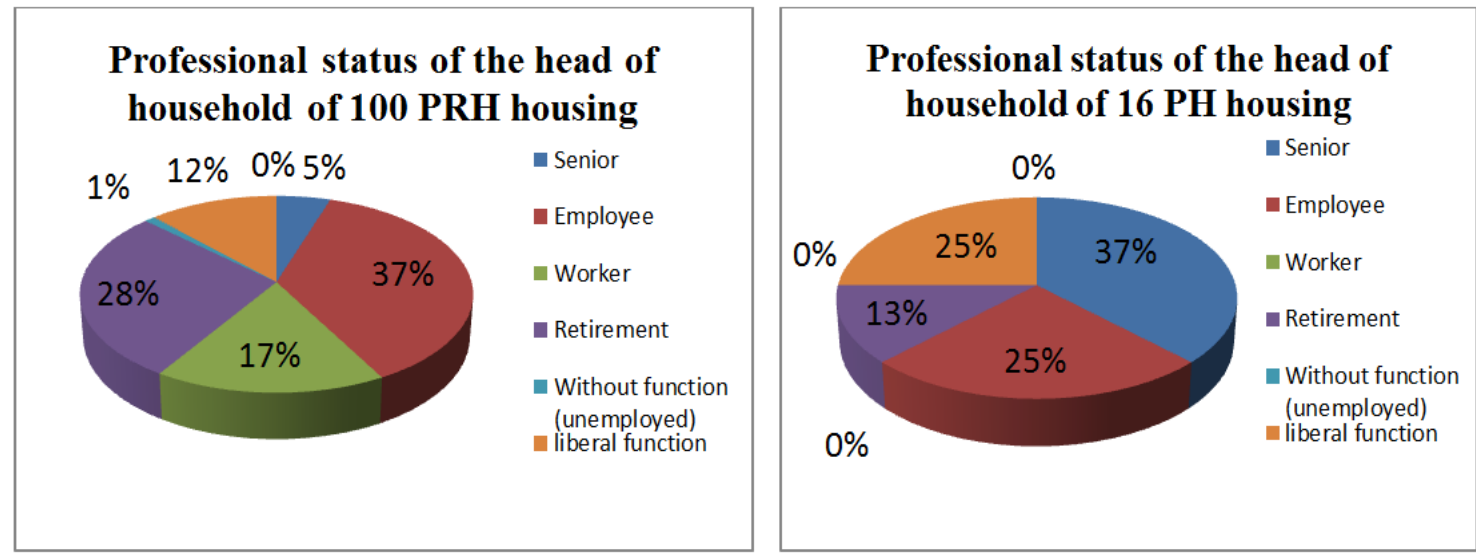

Source: Prepared by the authors, 2020.

- $\quad$ Transformation's study

The shape of the building:

The study results show that the two types of transformations were carried out by the occupants to different degrees. The soft transformations concern mainly; the aesthetic and work improvement (carpentry, painting, etc.), which they were carried out in all the dwellings of both types. In the case of the hard transformations, only the PRH housings were affected by this aspect and the different transformations carried out are presented below according to the variant.

ACE, 16 (47) CC BY-ND 3.0 ES | UPC Barcelona, España | Flexible Design in Algerian Collective Housing. Case of the New City Ali Mendjeli, Constantine. DOI: http://dx.doi.org/10.5821/ace.16.47.10030 


\section{- $\quad$ Transformations Variant 1}

The 3BR of PRH type of housing has an area of $65.59 \mathrm{~m}^{2}$ and a beam-columns structural system. According to Figure 6, 9 we see that all the dwellings (12 dwellings) of this type have undergone hard transformations through:

- The removal of the wall separating the living room from the balcony by transforming the baluster of the latter into a wall with a large or small window as an opening to enlarge the internal space which was the case for about (83.33\%) and change of room use for (66.67\%) of the number of cases studied.

- $\quad$ Change the location of the living room access door for (33.33\%).

- $\quad$ The removal of the wall that separates the dryer from the kitchen with a change in the location of the worktop as well as the various pipes for (75\%).

- We noted also that the wall of the dryer is transformed into a veranda.

- $\quad$ The removal of the wall that separates the bathroom from the toilet by transforming the space into a Shower room for (33.33\%) of cases investigated.

\section{- $\quad$ Transformations Variant 2}

The 3BR of PRH type of housing has an area of $\left(76.17 \mathrm{~m}^{2}\right)$ and a beam-columns structural system. According to Figure7, 9 all the dwellings (24 dwellings) of this type have undergone hard transformations through:

- The removal of the wall separating the living room from the balcony by transforming the baluster of the latter into a wall with a large or small window as an opening which was the case for about (79.17\%) while dividing the internal space in half to have one more room for (87.5\%) of the number of cases studied.

- $\quad$ Change of location of the living room access door for (87, 5\%).

- $\quad$ The removal of the wall that separates the dryer from the kitchen, with a change in the location of the worktop and the various pipes for (75\%). Note that the wall of the dryer is transformed into a veranda.

The removal of the wall that separates the bathroom from the toilet by transforming the space into a shower room for (37.5\%) of cases investigated.

\section{- $\quad$ Transformations Variant 3}

The 3BR of PRH type of housing has an area of $74.73 \mathrm{~m}^{2}$ and a load-bearing wall structure. According to (Figure 8, 9); we note that all the dwellings (64 dwellings) of this type have undergone heavy transformations through:

- The removal of the wall that separates the living room from the balcony transforming the baluster of the latter into a wall with a large or small window as an opening for about (26.56\%) of cases investigated, while dividing the internal space in half to have one more room for only $(1.56 \%)$.

- $\quad$ The removal of the wall that separates the dryer from the kitchen, with a change in the location of the worktop as well as the various pipes for (29.69\%). Note also that the dryer wall is transformed into a veranda.

\section{- $\quad$ Transformations PPH}

All the occupants of the PPH units are satisfied with the construction structure (beam-columns structural) of their units, or (100\%), which indicates a total absence of hard transformations, because their dwellings are large enough to meet their needs. Likewise, these occupants had the advantage of asking the developer to carry out the necessary transformations with rigorous monitoring according 
to their needs before occupation, since these dwellings were acquired with the plan purchase procedure (Figure 9).

Figure 6. Architectural Plans of 3BR units of the initial architectural plan PRH housing program with the different transformed plans (variant 1)

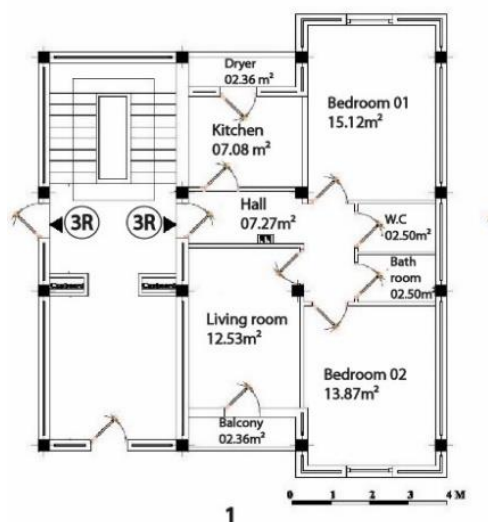

1

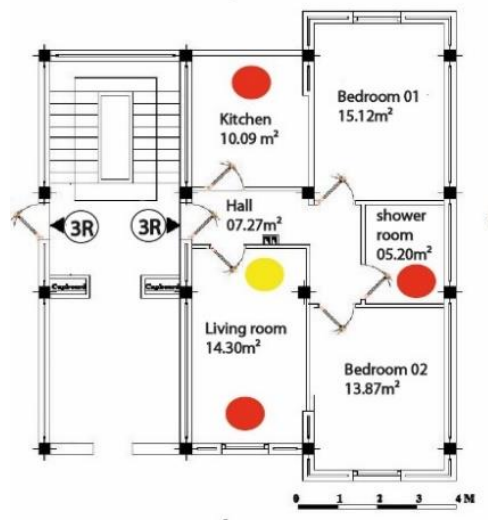

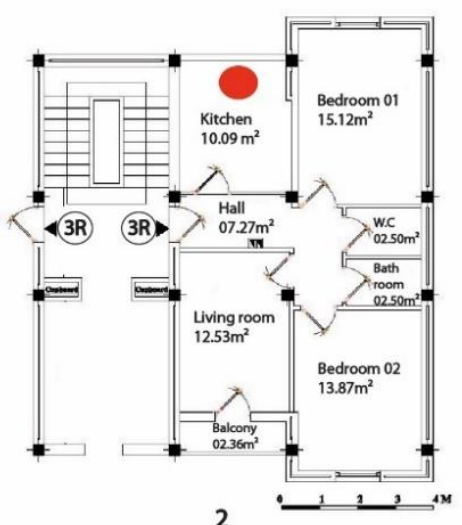

2

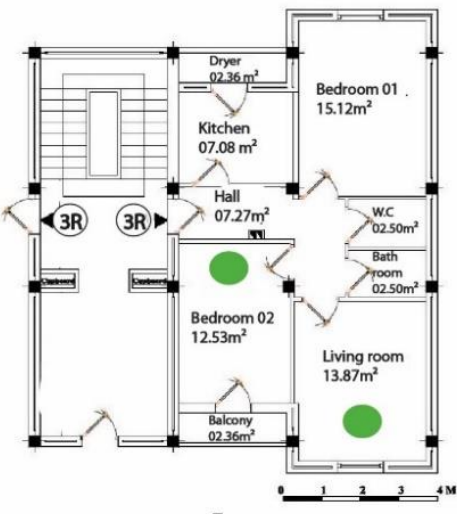

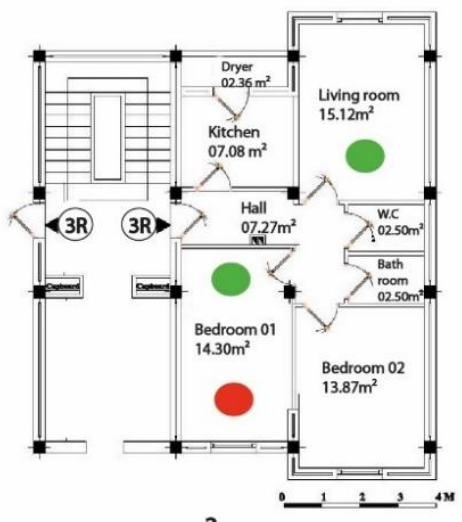

3

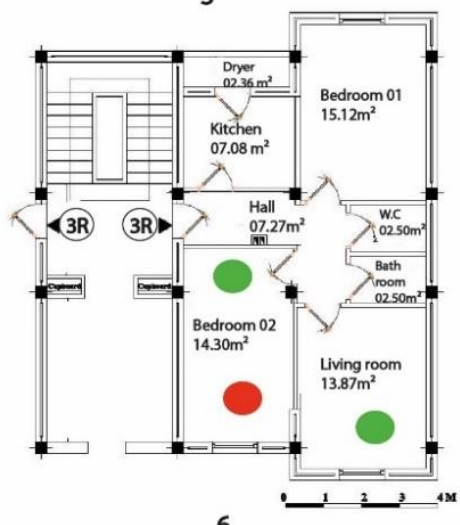

6

Elimination of the separation wall, either between Kitchen / Dryer or Living room / Balcony Either between the wall that separates the bathroom with the WC to have a Shower room Change of use of the room between Bedroom and Living room.

Change of location of the living room access door.

1- Initial plan of cell $3 R$ of type RPH variant 1

2-3-4-5-6 - The different transformed plans

3R Apartment with 3 bedrooms

Source: Prepared by the authors, 2020

- $\quad$ Lifestyle and Use of Space

According to the analysis and the field survey, for the two types of housing there is a difference in the use of internal spaces:

- $\quad$ (90\%) of families use the living room as a place to meet, relax, receive guests, watch TV, eat, and have some sleep in the case mainly of large families of more than 5 people. The rest, (10\%) of families use it, only as a place to meet, relax, receive guests, and watch TV this especially for small families less than 5 people.

- $\quad$ The parents' room is used for sleeping, working, reading, and watching TV. Likewise, the children's room is used for sleeping, studying, watching TV, and sometimes receiving guests and taking meals, for large families (9 people).

- $\quad$ The Hall is used as a space for circulation and drying clothes. 
- $\quad$ The bathroom is a space for body care and relaxation; it is also used as a place for washing and drying clothes.

- The kitchen as a crossroads of family life and a place to prepare meals, it is used for the reunion of the family group, to eat, and prepare different meals. However, in addition to the activities mentioned above, it is even used as a sleeping place for large families. (Table 2).

Figure 7. Architectural plans of 3BR unit of the PRH housing program initial architectural plan with the different plans transformed (variant 2)
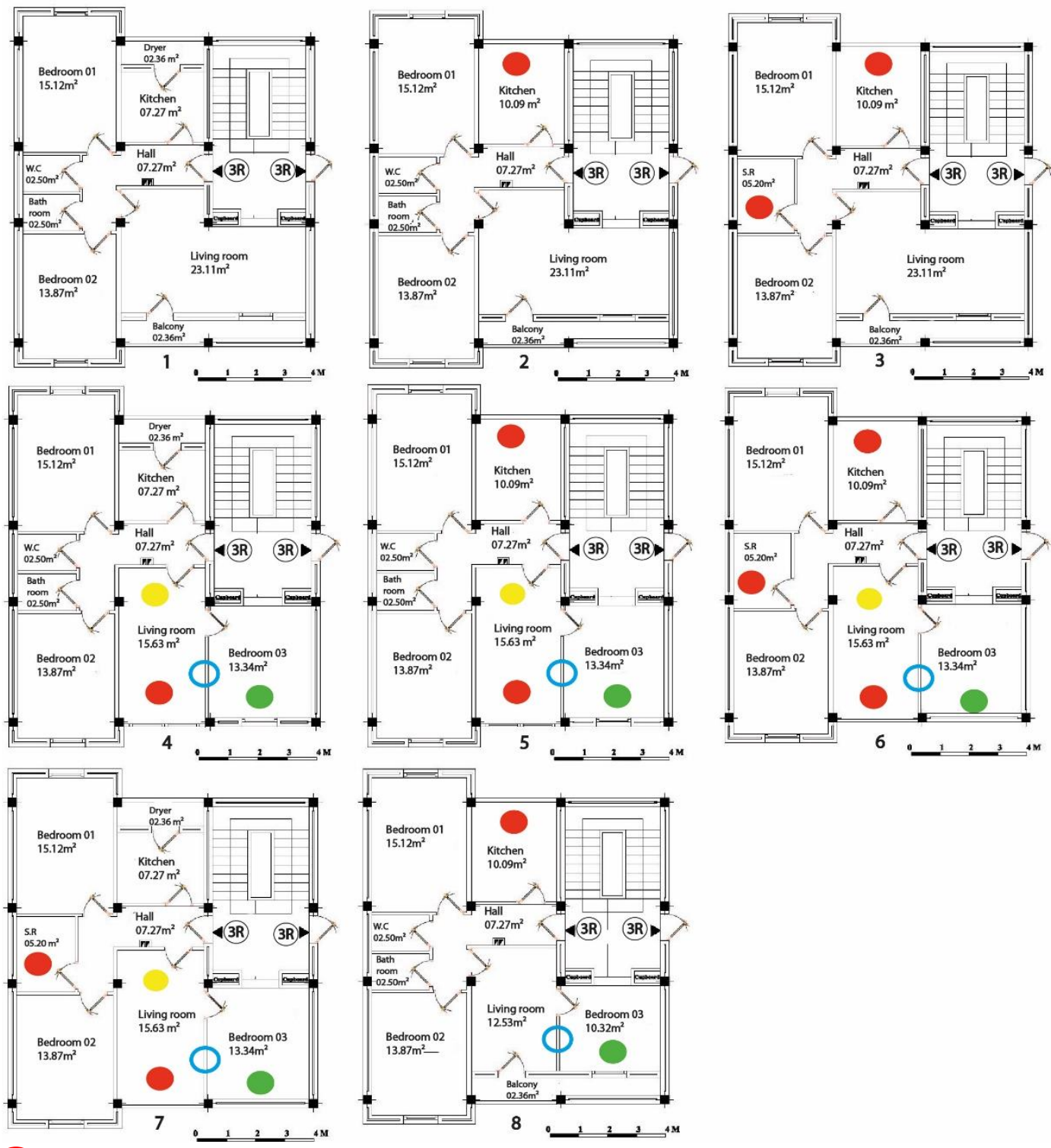

Elimination of the separation wall, either between Kitchen / Dryer or Living room / Balcony; Between the walls that separates the bathroom with the WC to have a Shower room.

Change of use of the room between Bedroom and Living room.

-1- Initial architectural plan of 3BR unit of PRH type variant 2

-2-3-4-5-6-7-8- The different transformed architectural plans.

Add a wall in the living room and have another bedroom.

Change of location of the living room access door.

3R Apartment with 3 bedrooms

Source: Prepared by the authors, 2020 
Figure 8. Architectural Plans of a 3BR dwelling of the housing program PRH initial
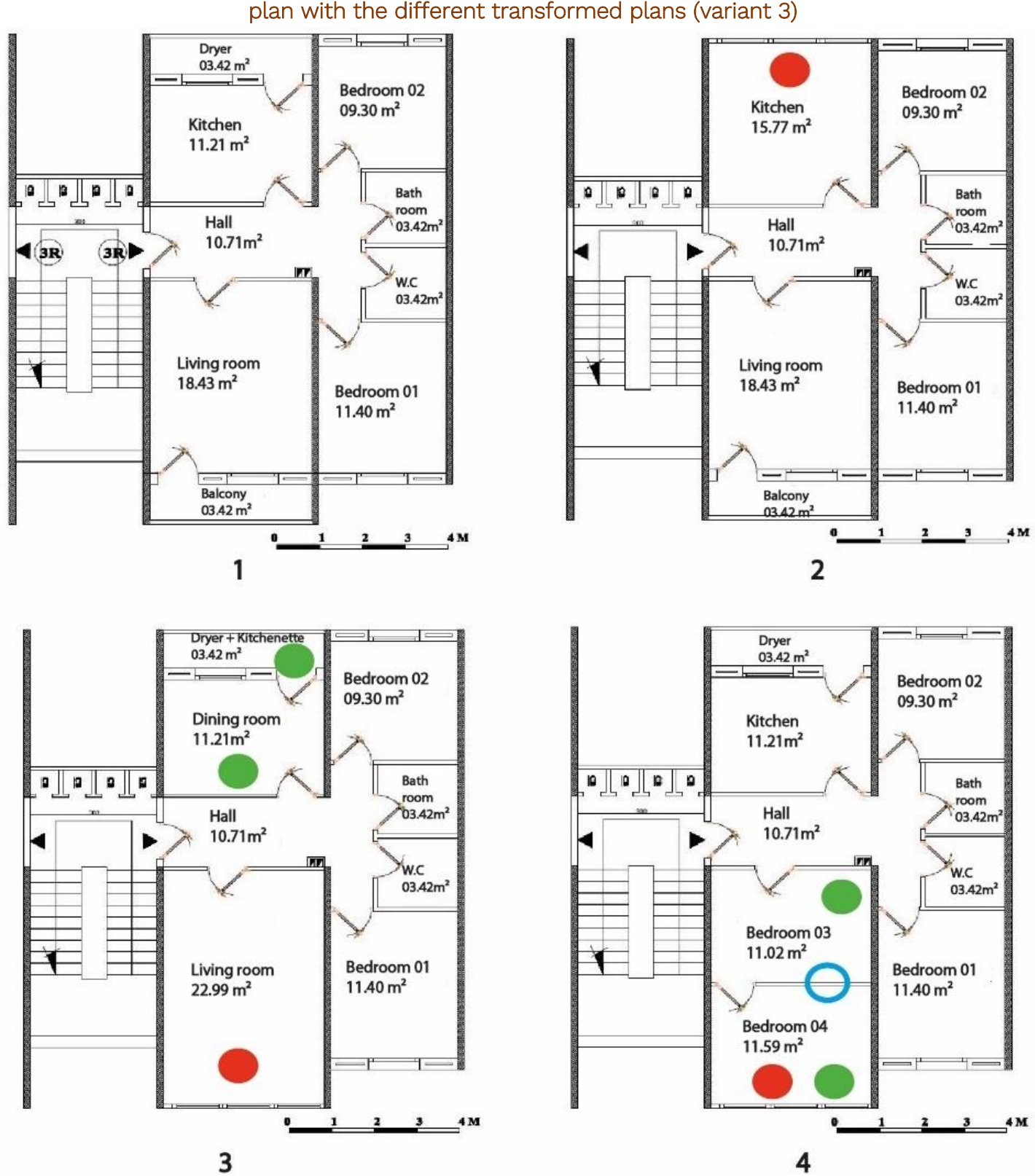

Elimination of the separation wall, either between Kitchen / Dryer or Living room / Balcony

Change of use of the living room to two bedrooms and the kitchen to a dining room and the dryer in the kitchen area

-1- Initial architectural plan of 3BR dwelling of PRH type variant 3

-2-3-4- The different transformed architectural plans

Add a wall in the living room and have another bedroom

Source: Prepared by the authors, 2020.

ACE, 16 (47) CC BY-ND 3.0 ES | UPC Barcelona, España | Flexible Design in Algerian Collective Housing. Case of 
Figure 9. Hard transformations in the various 1, 2 and 3 of $(\mathrm{PRH})$ dwellings and in (PPH) dwellings

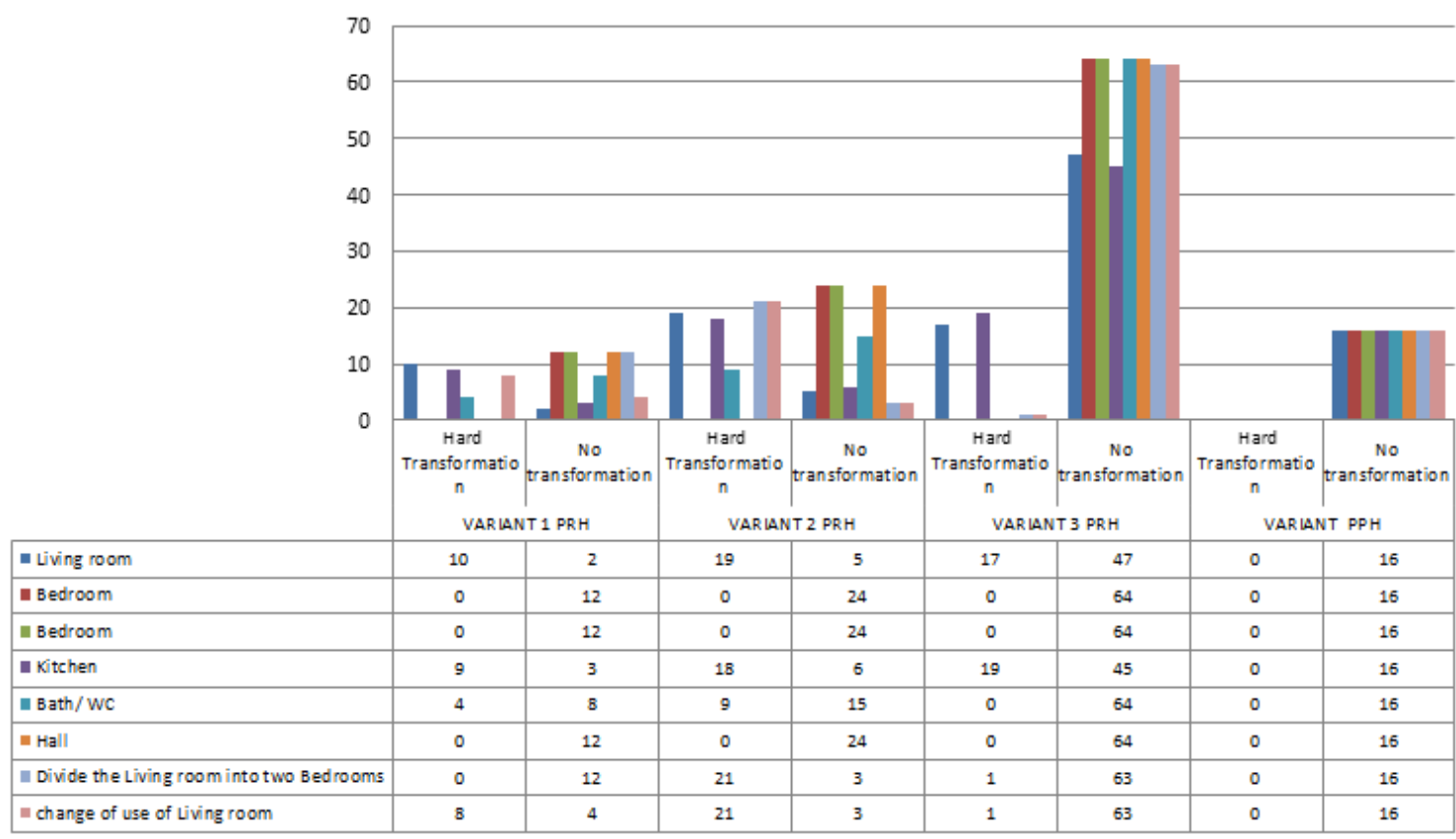

Source: Prepared by the authors, 2020.

Table 2. Different uses of rooms in the dwelling

\begin{tabular}{|c|c|c|c|c|c|c|}
\hline $\begin{array}{l}\text { The different } \\
\text { rooms }\end{array}$ & Living room & Children's room & $\begin{array}{l}\text { Parent's } \\
\text { room }\end{array}$ & Kitchen & $\begin{array}{l}\text { Bathroom } \\
\text { /WC }\end{array}$ & $\begin{array}{l}\text { Balcony } \\
\text { Dryer }\end{array}$ \\
\hline $\begin{array}{l}\text { Use of } \\
\text { domestic space } \\
\text { in families with } \\
\text { less than five } \\
\text { people }\end{array}$ & $\begin{array}{l}\text { Sitting, dining } \\
\text { Watch TV, } \\
\text { Meet } \\
\text { Greet guests }\end{array}$ & $\begin{array}{l}\text { To sleep } \\
\text { To study } \\
\text { Watch TV, }\end{array}$ & $\begin{array}{l}\text { Sleep } \\
\text { Study } \\
\text { Watch TV, }\end{array}$ & $\begin{array}{l}\text { Cook } \\
\text { Eat }\end{array}$ & Bathing & $\begin{array}{l}\text { Drying } \\
\text { clothes }\end{array}$ \\
\hline $\begin{array}{l}\text { Use of } \\
\text { domestic space } \\
\text { in families more } \\
\text { than five people }\end{array}$ & $\begin{array}{l}\text { Sitting, dining } \\
\text { Watch TV, } \\
\text { Meet } \\
\text { Greet guests, } \\
\text { Sleep, Study }\end{array}$ & $\begin{array}{l}\text { Sleep } \\
\text { Study } \\
\text { Watch TV } \\
\text { Sitting, } \\
\text { Welcoming } \\
\text { guests }\end{array}$ & $\begin{array}{l}\text { To sleep } \\
\text { To study } \\
\text { Watch TV, }\end{array}$ & $\begin{array}{l}\text { Cook } \\
\text { Eat } \\
\text { Study } \\
\text { Sleep }\end{array}$ & $\begin{array}{l}\text { Bathing } \\
\text { Change the } \\
\text { use of the } \\
\text { bathroom } \\
\text { used as a } \\
\text { kitchen }\end{array}$ & $\begin{array}{l}\text { Used as } \\
\text { kitchen area } \\
\text { Where to } \\
\text { remove } \\
\text { either } \\
\text { balcony or } \\
\text { dryer }\end{array}$ \\
\hline
\end{tabular}

Source: Prepared by the authors, 2020 .

\subsection{Results discussion}

The results for the evaluation for both spatial and structural satisfaction degrees of occupants within the modes of appropriation of spaces after transformation and adaptation are discussed to estimate the degree of flexible housing design.

\section{- Spatial satisfaction}

The study of the satisfaction level of the occupants in terms of organization and spatial arrangement differs from one dwelling to another for the two types (PRH and $\mathrm{PPH}$ ). Only the owners have carried out this type of transformation: 
- It was noted that all the occupants of the PRH type for all variants 1, 2 and 3 are (100\%) satisfied with their dwellings in terms of orientation, shape, and access arrangement. This is because the orientation with opposite facades provides sufficient lighting and natural ventilation et allows rotation in arrangement of spaces between Day and Night. Moreover, their regular and compact shape attributes a lot of potential in terms of change in number and size of the available rooms. Finally, a central position of the dwelling access, which allows having a direct connection between the different rooms.

- Whereas the occupants of the PPH dwellings type their satisfaction with the same criteria considered in the first case is variable. (70\%) of the occupants are not satisfied with their dwellings in terms of orientation and form, because they are designed with two-way orientation adjacent facades, which have as result less light and natural ventilation and give little opportunity for rotation in the arrangement of areas between day and night. Moreover, the elongated shape gives less potential in terms of change in number and size of the available rooms. Finally, even though most of the inhabitants are satisfied with their dwellings in terms of the central position of the access, but with an elongated plan shape and a larger size it does not allow a direct connection to the different rooms and does not facilitate the rotation between the Day/Night zones.

The analysis of the satisfaction level of the inhabitants with respect to the size of the dwellings varies from one type to another:

- $\quad$ The occupants of PRH dwellings of the three variants, (95\%) of them are not satisfied with this criterion because most families about (89\%) have more than 4 people per dwelling with a TOL of (5.9) higher than that defined by Constantine province of (5.7). A small area is much reduced due to the changing needs of the family; this pushes the occupants to carry out the various heavy transformations. (Figures 6, 7, 8 and 9).

- $\quad$ As for the occupants of PPH dwellings, (88\%) of them are satisfied with this criterion, since the family size does not exceed 5 people per dwelling, with a TOL of (4.5) by contribution to the size of the dwelling and a TOP of (1.5). Therefore, their area is perfectly suited to the different daily activities of the family, and nothing has been noted.

The study of the technical services position in the two types of dwellings indicates that:

- Apart from the kitchen position along one of the two opposite facades, which is well placed for all occupants, the half of the occupants of PRH housing type about (49\%), consider that the arrangement of the bathroom and the toilettes are on the side of the blind wall of the building, even if centralized, they do not provide the conditions required for good ventilation, as a result some have created openings on the wall.

- Similarly, for the kitchen position of the PPH dwellings, the occupants appreciate its arrangement, which is placed along one of the two adjacent facades shared with another dwelling. As for at the placement of the bathroom and the toilettes, they are along the party wall with another dwelling, which exposes its occupants to poor ventilation and bad smells, making (50\%) of occupants not satisfied. (Figure 10).

\section{- $\quad$ Structural satisfaction}

The study of the satisfaction level of the occupants with respect to the structure of housing construction concerns only the $\mathrm{PRH}$ and it differs from one variant to another depending on the type of structure:

ACE, 16 (47) CC BY-ND 3.0 ES | UPC Barcelona, España | Flexible Design in Algerian Collective Housing. Case of 19 the New City Ali Mendjeli, Constantine. DOI: http://dx.doi.org/10.5821/ace.16.47.10030 
- The occupants of PRH dwellings with a beam-columns structural system, variant 1, 2, are all satisfied, or (100\%), because it allows them to perform hard transformations with ease.

- $\quad$ As for those occupying the PRH, with a structure in load-bearing walls, variant 3, about (78\%) of them with a large family more than 5 people are not satisfied, because any change is difficult and directly affect the stability of all building. However, we note certain transformations in the walls of the living room facade with for (26.56\%) and that of the kitchen for (29.69\%) of the inhabitants.

- All the occupants of the PPH units are satisfied with the construction structure (beamcolumns structural) of their units, or (100\%), which indicates a total absence of hard transformations, because their dwellings are large enough to meet their needs. Likewise, these occupants had the advantage of asking the developer to carry out the necessary transformations with rigorous monitoring according to their needs before occupation, since these dwellings were acquired with the plan purchase procedure (Figure 11).

Figure 10. The degree of spatial satisfaction for the 100 dwellings in the $\mathrm{PRH}$ at NU8 and 16 dwellings in the PPH at NU5

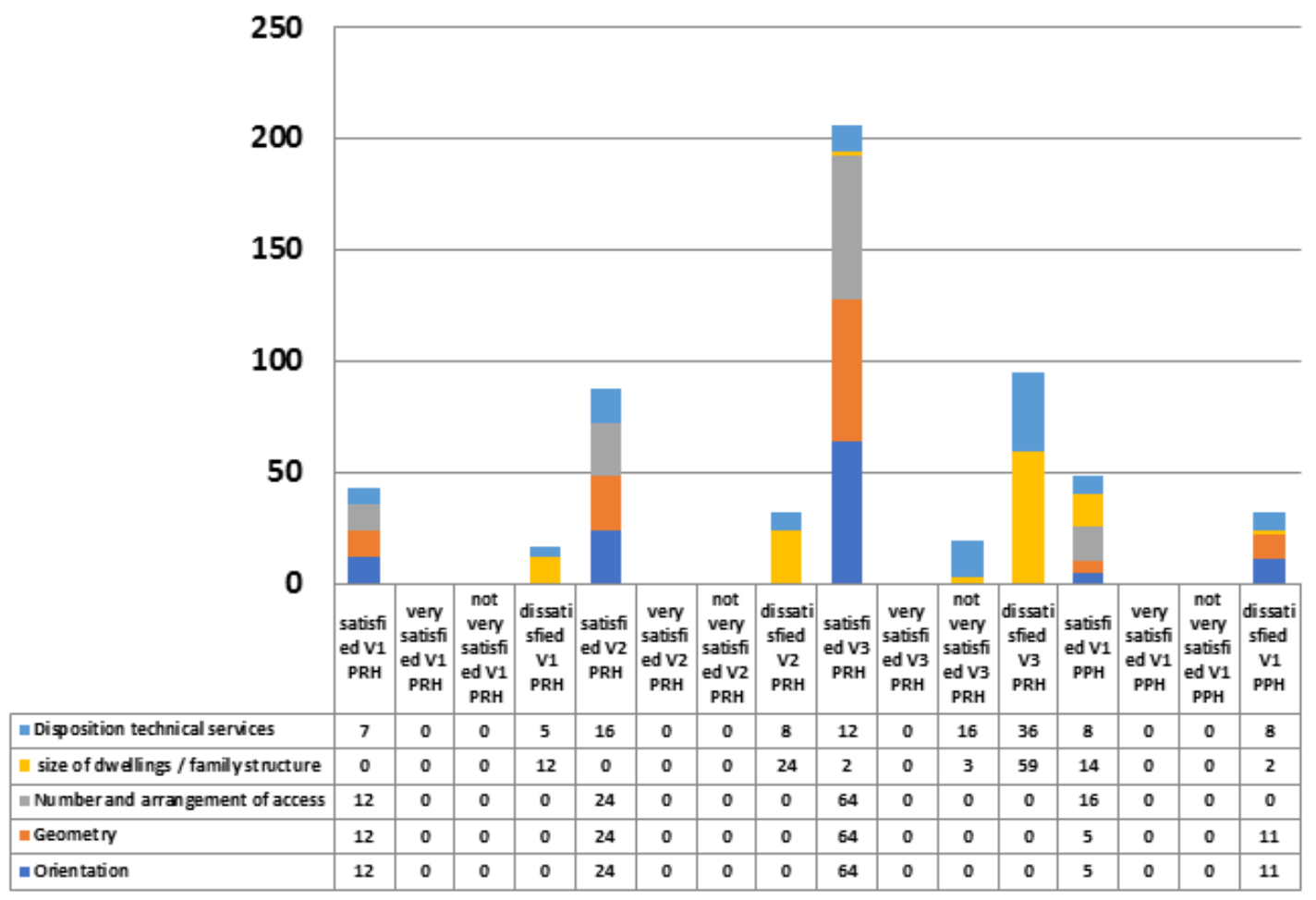

Source: Prepared by the authors, 2020.

- Modes of appropriation of spaces

It has been found that there is versatility in the use of the room's both at day and night and this differs from one family to another according to their needs and size. (Table 2) Such as, -within the absence of terrace spaces, carpets are washed in the staircase landings, - living rooms which are used for multiples functions are enlarged by adding balcony surface removing separate wall and -for more privacy, access to living rooms are changed. (Figure 12) However, small families of less than 5 people use the space with reasonable versatility, maintaining the main functions of the rooms.

ACE, 16 (47) CC BY-ND 3.0 ES | UPC Barcelona, España | Flexible Design in Algerian Collective Housing. Case of the New City Ali Mendjeli, Constantine. DOI: http://dx.doi.org/10.5821/ace.16.47.10030 
Figure 11. The degree of structural satisfaction for the 100 dwellings in the PRH at NU8 and 16 dwellings in the PPH at NU5

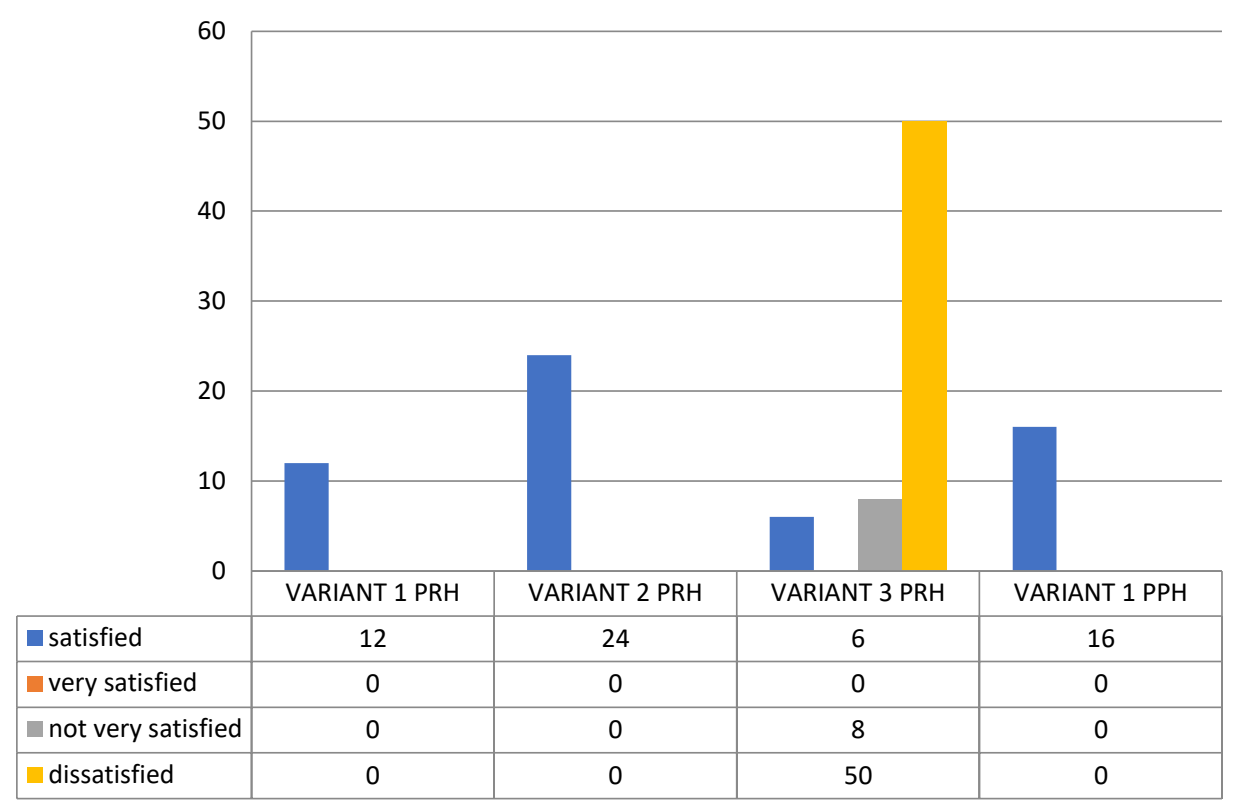

Source: Prepared by the authors, 2020.

Figure 12. (a) Enlarging the living room by removing the wall that separates the living room/ balcony,

(b) Changing access to the living room, (c) Washing the carpet in the landing the staircase

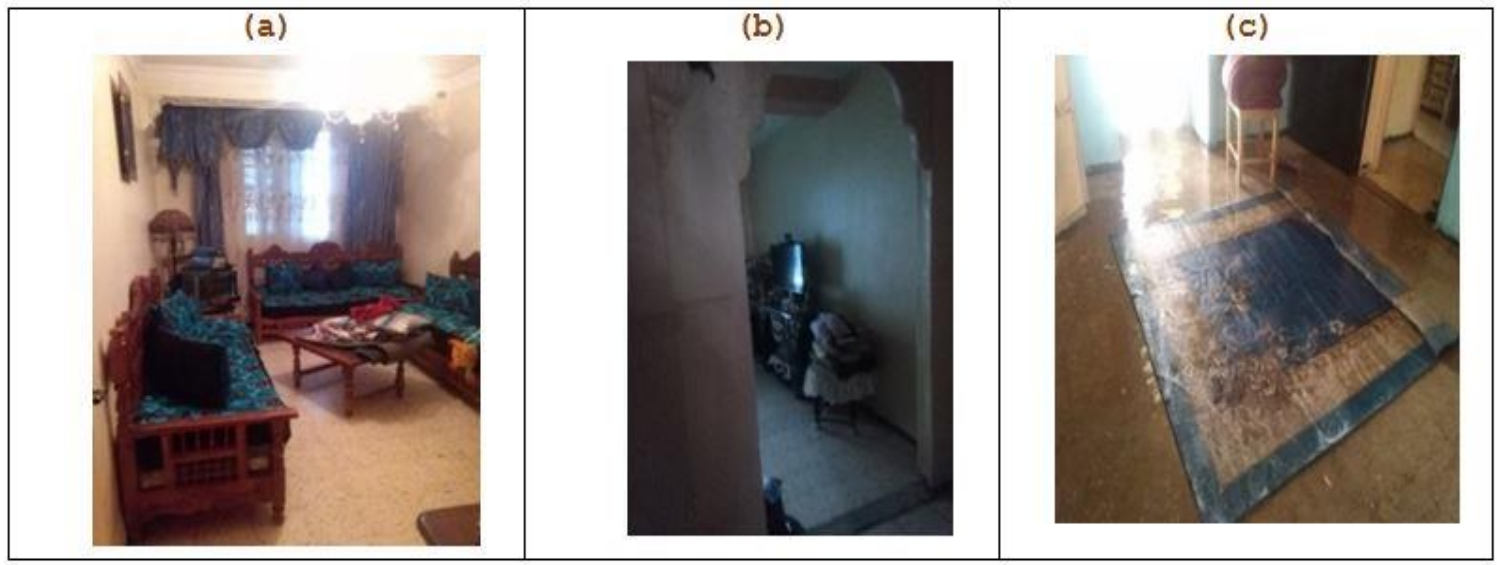

Source: Authors, 2020

- $\quad$ The comparative analysis between dwelling types

According to the construction criteria studied, it can be noted that there are similarities and differences in the satisfaction of users in terms of space and structure within the two types of housing $\mathrm{PRH}$ and $\mathrm{PPH}$.

- Both housing types have a single access with a central position (analysis and results) that allows, according to the indicators (Number and disposition of the entrance), a rotation between day and night spaces. Likewise, both types have undergone slight transformations for better aesthetic appearance. 
However, the differences between the two dwellings are characterized by:

- A two-sided orientation with two opposite facades for the PRH dwellings and two adjacent facades for the PPH dwellings (analysis and results), hence the difference in the degrees of spatial satisfaction, compared to the orientation indicator, which are respectively of $100 \%$ and 70\% (The orientation of dewelling) (Figure 10).

- A regular shape for both types but a simple and compact architectural plan for PRHs a simple and elongated geometric plan for PPHs (analysis and results) and thus degrees of spatial satisfaction with respect to the indicator geometric plan, are respectively of $100 \%$ and $70 \%$ (The plan geometry). This reveals an ease of establishing heavy transformations in the HPP dwellings of the two variants 1 and 2. (Figure 9, 10).

- A small housing size for F3 type PRHs, of $65-76 \mathrm{~m}^{2}$ surface areas in relation to large family structure varying from 4 and 9 persons. On the other hand, a housing size is largely sufficient for PPHs of F3 type, of $111 \mathrm{~m}^{2}$ of surface area in relation to family structure varying from 3 to 5 persons (analysis and results). According to the indicators mentioned in (Size of dewelling in relation to the family structure), a flexible design that links housing size with family structure gives a spatial satisfaction level of $88 \%$ for $\mathrm{PPH}$ dwellings occupants, but a dissatisfaction level of 95\% for the three variants PRH dwellings occupants. The latter justifies the various heavy transformations carried out in these dwellings and thus indicates a freedom in the organization and spatial appropriation resulting in a satisfactory degree of flexible design (Figure 9, 10, 13, 14).

Figure 13. Facade of PPH housing type at NU5
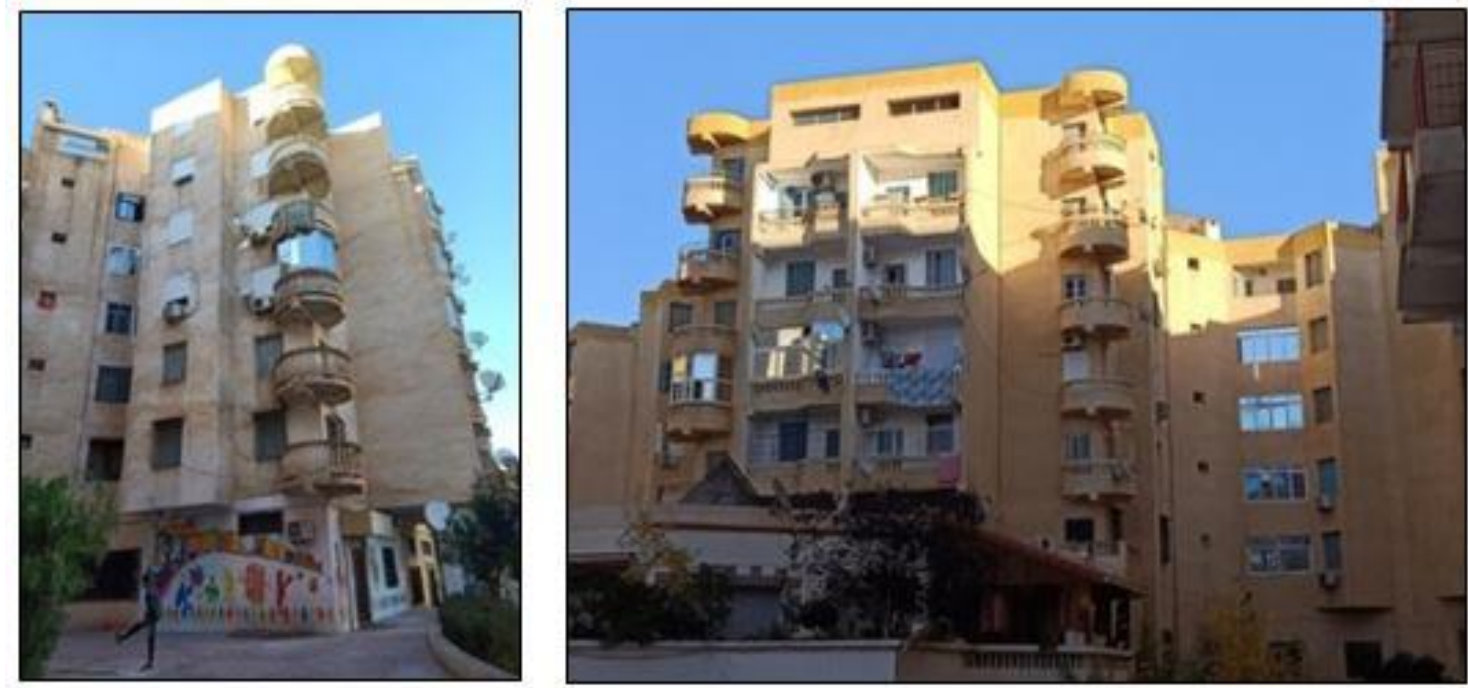

Source: Prepared by the authors, 2020.

The two types of housing PRH and PPH are marked by a separate placement of technical services (kitchen, bathroom, and WC) (analysis and results), (Technical services position). Despite the central arrangement of part of these, namely bathroom and WC, in the three variants of PRH housing, which offers more flexibility and freedom in their spatial organization, many occupants are dissatisfied with their housing, i.e., 49\%. Conversely, the same services in PPH housing are installed along the party wall with another housing, with generates less flexibility and dissatisfaction for a large part of their occupants, i.e., $50 \%$.

This dissatisfaction is mainly due to poor construction of the ventilation ducts which produces bad odors. For this purpose, the occupants of the PRH housing created openings in the façade of the blind wall, i.e., heavy transformations. (Figure 10, 14).

ACE, 16 (4.7) CC BY-ND 3.0 ES | UPC Barcelona, España | Flexible Design in Algerian Collective Housing. Case of 22 the New City Ali Mendjeli, Constantine. DOI: http://dx.doi.org/10.5821/ace.16.47.10030 


\section{ACE Architecture, City and Environment}

E-ISSN1886-4805

Figure 14. (a) Facade of housing type PRH variant 3 Transformations with creation of openings for sanitary facilities, (b) Facade of housing type PRH to NU8 variant 1, 2 shows the different transformations in facade

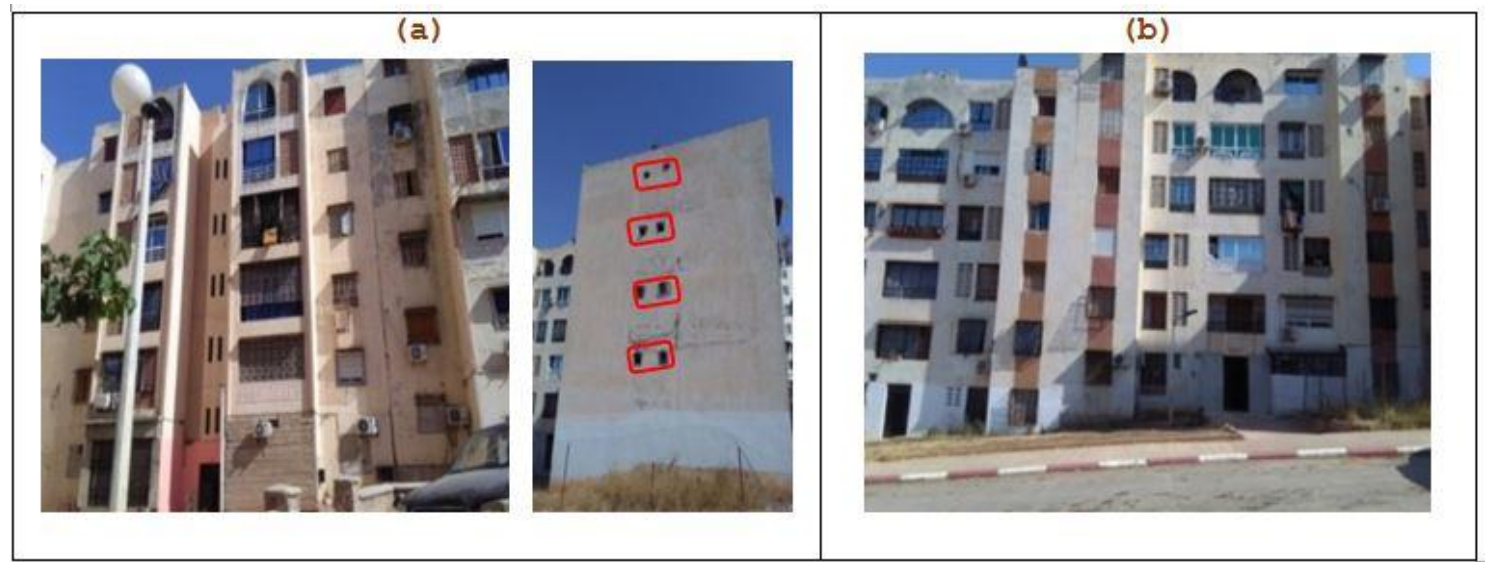

Source: Prepared by the authors, 2020.

According to indicators cited in (Construction structure), the portal structure type (column-beam) for variants 1 and 2 of PRH and PPH housing offers more opportunity for spatial organization and a high degree of spatial flexibility (analysis and results). In contrast, the load-bearing wall structure type for variant 3 of the $\mathrm{PRH}$ housing limits the flexibility of spaces and gives a degree of dissatisfaction of (78\%). Thus, the first type of structure facilitates heavy transformations in variants 1 and 2 to allow different ways of appropriation (Figure 6, 7, 8, 9, 11).

\section{Conclusion}

In conclusion, it should be noted that through the analysis of construction criteria - adaptation and transformation- identified above, the elements composing the $\mathrm{PRH}$ and $\mathrm{PPH}$ housing examples examined, deserve special attention from architect designers for spatial and structural satisfaction of users. Indeed, the theoretical study shows that a better use of adaptation and transformation indicators, such as geometric plan, access, orientation, size and shape, technical services and housing structure, allows flexible design. This analysis has shown that indeed these criteria must be taken into consideration in the initial spatial design of these dwellings to achieve an optimal degree of spatial appropriation and flexibility.

However, it was found that the flexible design in these dwellings presents a degree of spatial flexibility that varies from housing unit to another and by type. Certainly, the degree of flexible design in the $\mathrm{PPH}$ housing compared to the PRH housing is much more satisfactory in spite of the adjacent bilateral orientation of their facades and the poor position of their technical services. However, it is the indicator of the housing large size in relation to the family small size, which allows the satisfaction of the spatial needs et also thanks to the "purchase on plan" procedure that permits the choice.

As for the PRH housing with column-and-beam structure for variants one and two, they present a satisfactory flexibility in all adaptation and transformation indicators apart from the one concerned by the housing small size in relation to family large size. The latter can achieve optimal spatial flexibility if they are addressed to a small family size (4 inhabitant's maximum). As for variant 3, in addition to the relation indicator housing size/family size, its flexibility degree is further reduced by the construction structure indicator which restricts transformations.

ACE, 16 (47) CC BY-ND 3.0 ES | UPC Barcelona, España | Flexible Design in Algerian Collective Housing. Case of 23 the New City Ali Mendjeli, Constantine. DOI: http://dx.doi.org/10.5821/ace.16.47.10030 
Therefore, $\mathrm{PRH}$ dwellings that are small should only be addressed to small family's size, with a maximum of 4 inhabitants per dwelling, to maintain better spatial and structural satisfaction, and thus an optimal degree of flexible design. For large family's size, large surface, and flexible structure (column-beam) dwellings such as PRH type dwellings with respect to construction criteria are to be considered in the planning of collective social housing in Algeria.

In conclusion, criteria that indicate the presence of flexible design in theory are taken into consideration indirectly in the design of most Algerian social collective housing. However, the problem occurred in small dwellings that are occupied by family of larger sizes.

\section{Acknowledgments}

The authors would like to express their gratitude to the interviewees, the citizens and the planner offices of Ali Guechi and Ziani; in addition, the (DUAC) Direction of Urbanism of Architecture and Construction wilaya of Constantine for their valuable contributions to this research

\section{Authorship}

Both authors have conceptualized and developed this investigation and have written the article.

Conflict of interests: The authors declare that there is no conflict of interest

\section{Bibliography}

Albostan, D. (2009). Flexibility in multi-residential housing projects: three innovative cases from Turkey. Thesis of master's in architecture. Department of Architecture, Middle East Technical University.

Angadi, H. (2014). Ré- appropriation par les usagers de l'espace habité cas de la ville de Tlemcen. Thèse de magistère, université Abou Bakr Belkaid-Tlemcen, faculté de technologie, Département d'architecture, option la ville, patrimoine et urbanisme.

Khalkhali, Z. B. (2019). Applying a life cycle approach in designing flexible housing, Master of Architecture, Unitec Institute of Technology.

Benbouaziz, A. (2011). Les transformations architecturale et morphologiques de l'habitat traditionnel dans les Aures: Cas de Menaa. Magister thesis, Mohamed Khider-Biskra University, Faculty of Science and Technology, Department of Architecture and Urban Planning, option: architecture in arid and semi-arid environments.

Benrachi, B. (2004). Evaluation de le Relation entre les Exigences Techniques et le Coût de Construction des Logements Collectifs: Cas de Constantine. Constantine State Doctoral Thesis: Mentouri University of Constantine, Faculty of Earth Sciences and Spatial Planning, Department of Architecture and Urban Planning, option: architecture.

Benrachi, B., Lezzar, S. (2013). The impact of building modifications on Algerian social collective housing. International Journal of Urban Sustainable Development, 6(1), 123-132. DOI: $\underline{10.1080 / 19463138.2013 .780176}$

ACE, 16 (47) CC BY-ND 3.0 ES | UPC Barcelona, España | Flexible Design in Algerian Collective Housing. Case of 
Bourahli, R.M. (2009). Le logement promotionnel en Algérie Entre l'ordinaire et le standing Cas de la nouvelle ville Ali Mendjeli-Constantine. Mémoire de magister, Université Constantine, Faculté de l'Aménagement du Territoire, Département d'Architecture et d'Urbanisme.

Le Breton, A. (2015). La pérennité du logement collectif, l'habitat évolutif, une réponse au temps qui passe? mémoire de master. Ecole Nationale d'Architecture de Clermont Ferrand.

Bullivant, L. (Ed.) (2005). 4Dspace: Interactive Architecture, Wiley-Academy.

Chatelet, A.M., Eleb-Vidal, M., Mandoul, T. (1995). Penser l'habité, le logement en questions, Bruxelles, Edition Pierre Mardaga.

Direction de l'urbanisme de l'architecture et de la construction wilaya de Constantine (DUAC). (2010). Fiche technique de la Ville Nouvelle ALI MENDJELI. Constantine.

Estaji, H. (2017). A Review of Flexibility and Adaptability in Housing Design., International Journal of Contemporary Architecture 4(2), 37-49. DOI: 10.14621/tna.20170204

Friedman, A. (2001). The Grow Home, McGill-Queen's University Press.Montreal.

Frommes, B. (1980). Le logement dans son environnement. Luxembourg.

Foura, Y. (2007). Typification, standardisation et homogénéisation des logements et ensembles d'habitations: l'impact sur les permanences, les modèles culturels et l'habiter. Thèse de doctorat, Université Constantine, Faculté de l'Aménagement du Territoire, Département d'Architecture et d'Urbanisme.

Gilani, G. (2012). Evaluating Flexibility Notions in Mass Housing of North Cyprus through Learning from Her Rural Vernacular Architecture. Master of Science, Eastern Mediterranean University. http://irep.emu.edu.tr:8080/xmlui/bitstream/handle/11129/1268/Gilani.pdf?sequence=1

Groak, S. (1992). The Idea of Building: Thought and Action in the Design and Production of Buildings. Routledge. London.

Harper, R. (2003). Inside the Smart Home. Springer.

Haraoubia, I. (2011). La qualité du logement social en Algérie. Mémoire de master, École Nationale Supérieure d'Architecture de Marseille.

Sánchez, J. (2013). Flexible Design and the Role of the User in House Design. The Journal of the College of Architecture, Planning and Design at Kansas State University, 35, 68-73. DOI: 10.4148/2378-5853.1521

Broome, J. (2005). Mass housing cannot be sustained. In P B. Jones, D. Petrescu, \& J. Till (Eds.), Architecture and Participation (pp. 65). Routledge. https://www.taylorfrancis.com/chapters/mono/10.4324/9780203022863-9/mass-housing-cannotsustained-peter-blundell-jones-doina-petrescu-jeremy-till

Jora. (1986). Journal officiel N¹0. République Algérienne Démocratique et Populaire.

Jora. (1993). Journal officiel N¹4. République Algérienne Démocratique et Populaire.

Jora. (1994). Journal officiel N66. République Algérienne Démocratique et Populaire. 
Jora. (1998). Journal officiel N5, 199. République Algérienne Démocratique et Populaire.

Jora. (2000). Journal officiel N¹9. République Algérienne Démocratique et Populaire.

Jora. (2001). Journal officiel N¹6. République Algérienne Démocratique et Populaire.

Jora. (2001). Journal officiel N²5. République Algérienne Démocratique et Populaire.

Jora. (2001). Journal officiel N52. République Algérienne Démocratique et Populaire.

Kronenburg, R. (2007). Flexible une architecture pour répondre aux changements. Edition Norma.

Lamure, C. (1976). Adaptation du logement à la vie familial. Eyrolles.

Lans, W., Hofland, C. (2005). Flexibility, how to accommodate unknown future housing requirements. XXXIII IAHS World Congress on Housing: Transforming housing environments through design [Internet]; University of Pretoria, South Africa. https://repository.up.ac.za/handle/2263/10355.

Leghmouche, A. (2009). La qualité conceptuelle du logement promotionnel face aux aspirations des habitants cas de la ville nouvelle Ali Mendjeli. Constantine. Magistère en Architecture, option: Habitat et Environnement Urbaine, Faculté des Sciences de la Terre, de Géographie et de l'Aménagement du Territoire, Département d'Architecture et d'Urbanisme.

Lelieveld, C.M.J.L., Voorbij, A.I.M., Oelman, W. A. (2007). Adaptable Architecture. International conference of 21st century COE Program of Tokyo Metropolitan University (245-252). TAlHEI Printing Co., Ltd. http://tmu-arch.sakura.ne.jp/pdf/26_proc_bsa_e/Proceedings_pdf/245-252\%20031SS_B22.pdf

Lezzar, S. (2000). Le Vieillissement Prématuré du Patrimoine d'Habitation: Construction, Entretien et Législation. Magister's thesis, Constantine, Mentouri University of Constantine.

Ministère de l'habitat de l'urbanisme et de la ville. (2015). Politique gouvernementale dans le domaine de l'habitat, de l'urbanisme et de la ville.

ONS Office nationale des statistiques. (2020). Répartition du parc logement total des MOC selon la commune de résidence. Le statut d'occupation du logement, et le taux d'occupation du logement (TOL).

Rabeneck, A., Sheppard, D., \& Town, P. (1973). Housing Flexibility/Adaptability? Architectural Design, 43, 698-727.

Rifi, C.S (2008). Le logement collectif. Mécanismes pluriels pour une qualité architecturale singulière cas de la ville de Guelma. Faculté des Sciences de la Terre, de Géographie et de l'Aménagement du Territoire, Département d'Architecture et d'Urbanisme, Thèse de Magistère, Option : Habitat et Environnement Urbain.

Ritter, S., Nuno, C. (2018). Housing flexibility problem: Review of recent limitations and solutions. Review Frontiers of Architectural Research, 7(1), 80-91. DOI: 10.1016/i.foar.2017.11.004

Saez. M. (2012). Rapport d'étude: La flexibilité dans le logement collectif, une architecture qui s'adapte aux changements. Ensase.

ACE, 16 (4.7) CC BY-ND 3.0 ES | UPC Barcelona, España | Flexible Design in Algerian Collective Housing. Case of 
Saighi.O. (2005). Le phénomène de transformation du cadre physique au niveau du logement collectif cas de la ville nouvelle Ali Mendjeli Constantine. Thèse de Magistère, Université Farhat Abbas-Setif UFAS, Faculté des Sciences de l'Ingénieur, Département d'Architecture, Option Architecture, Histoire et Société.

Schnädelbach, H., Penn, A. \& Steadman, P. (2007). Mixed Reality Architecture: A Dynamic Architectural Topology. 6th International Space Syntax Symposium. https://discovery.ucl.ac.uk/id/eprint/5168/2/5168.pdf

Schnädelbach, H. (2010). Adaptive architecture- A Conceptual Framework. In Proceedings of MediaCity. http://www.cs.nott.ac.uk/ pszhms/Holger Schnadelbach - Research/Adaptive Architecture.html

Schneider, T. and Till, J. (2005 a). Flexible housing: opportunities and limits. Architectural Research Quarterly 9(2), 157-166. DOI: 10.1017/S1359135505000199

Till, J. and Schneider, T. (2005 b). Flexible housing: the means to the end. Architectural Research Quarterly 9(3/4), 287-296. DOI: 10.1017/S1359135505000345

Schneider, T and Till, J. (2007). Flexible Housing. Architectural Press.

Streitz, N. A., Siegel, J., Hartkopf, V. \& Konomi, S. I. (1999) Cooperative Buildings, Springer.

Tebbib, E. (2008). L'Habiter dans le Logement Social à Constantine: Manières et Stratégie d'Appropriation de l'Espace. Doctoral Thesis in Science. Constantine: Mentouri University of Constantine.

Živković, M., Jovanović, G. (2012). A method for evaluating the degree of housing unit flexibility in multifamily housing. University of Niš. Architecture and Civil Engineering 10(1), 17-32. DOI: 10.2298/FUACE1201017Z 